\title{
Response of benthic foraminifera to ocean acidification in their natural sediment environment: a long-term culturing experiment
}

\author{
K. Haynert ${ }^{1}$, J. Schönfeld ${ }^{1}$, R. Schiebel ${ }^{2}$, B. Wilson ${ }^{3}$, and J. Thomsen ${ }^{4}$ \\ ${ }^{1}$ GEOMAR Helmholtz Centre for Ocean Research Kiel, Wischhofstrasse 1-3, 24148 Kiel, Germany \\ ${ }^{2}$ University of Angers, Laboratoire des Bio-Indicateurs Actuels et Fossiles, LPG-BIAF, UMR6112 CNRS, 2 Boulevard \\ Lavoisier, 49045 Angers, France \\ ${ }^{3}$ Petroleum Geoscience Programme, Department of Chemical Engineering, University of the West Indies, St. Augustine, \\ Trinidad and Tobago \\ ${ }^{4}$ GEOMAR Helmholtz Centre for Ocean Research Kiel, Hohenbergstrasse 2, 24105 Kiel, Germany
}

Correspondence to: K. Haynert (khaynert@geomar.de)

Received: 13 May 2013 - Published in Biogeosciences Discuss.: 13 June 2013

Revised: 9 February 2014 - Accepted: 11 February 2014 - Published: 25 March 2014

\begin{abstract}
Calcifying foraminifera are expected to be endangered by ocean acidification; however, the response of a complete community kept in natural sediment and over multiple generations under controlled laboratory conditions has not been constrained to date. During 6 months of incubation, foraminiferal assemblages were kept and treated in natural sediment with $p \mathrm{CO}_{2}$-enriched seawater of 430 , 907, 1865 and $3247 \mu$ atm $p \mathrm{CO}_{2}$. The fauna was dominated by Ammonia aomoriensis and Elphidium species, whereas agglutinated species were rare. After 6 months of incubation, pore water alkalinity was much higher in comparison to the overlying seawater. Consequently, the saturation state of $\Omega_{\text {calc }}$ was much higher in the sediment than in the water column in nearly all $p \mathrm{CO}_{2}$ treatments and remained close to saturation. As a result, the life cycle (population density, growth and reproduction) of living assemblages varied markedly during the experimental period, but was largely unaffected by the $p \mathrm{CO}_{2}$ treatments applied. According to the size-frequency distribution, we conclude that foraminifera start reproduction at a diameter of $250 \mu \mathrm{m}$. Mortality of living Ammonia aomoriensis was unaffected, whereas size of large and dead tests decreased with elevated $p \mathrm{CO}_{2}$ from $285 \mu \mathrm{m}\left(p \mathrm{CO}_{2}\right.$ from 430 to $\left.1865 \mu \mathrm{atm}\right)$ to $258 \mu \mathrm{m}\left(p \mathrm{CO}_{2}\right.$ $3247 \mu \mathrm{atm}$ ). The total organic content of living Ammonia aomoriensis has been determined to be $4.3 \%$ of $\mathrm{CaCO}_{3}$ weight. Living individuals had a calcium carbonate production rate of $0.47 \mathrm{~g} \mathrm{~m}^{-2} \mathrm{a}^{-1}$, whereas dead empty tests accumulated a rate of $0.27 \mathrm{~g} \mathrm{~m}^{-2} \mathrm{a}^{-1}$. Although $\Omega_{\text {calc }}$ was close to 1 , ap-
\end{abstract}

proximately $30 \%$ of the empty tests of Ammonia aomoriensis showed dissolution features at high $p \mathrm{CO}_{2}$ of $3247 \mu \mathrm{atm}$ during the last 2 months of incubation. In contrast, tests of the subdominant species, Elphidium incertum, stayed intact. Our results emphasize that the sensitivity to ocean acidification of the endobenthic foraminifera Ammonia aomoriensis in their natural sediment habitat is much lower compared to the experimental response of specimens isolated from the sediment.

\section{Introduction}

Benthic foraminifera are the most diverse group of hardshelled protists. They live at the sediment-water interface, especially in the uppermost $0-1 \mathrm{~cm}$, or within oxygenated sediments down to $>12 \mathrm{~cm}$ depth (Corliss, 1985). It is expected that calcifying foraminifera will be adversely affected by the ongoing acidification of the oceans. Surprisingly, previous experimental studies did not report a consistent and uniform response when living specimens were subjected to simulated ocean acidification. Most benthic foraminifera showed hampered calcification by high $p \mathrm{CO}_{2}$ (Le Cadre et al., 2003; Kuroyanagi et al., 2009; Allison et al., 2010; Dissard et al., 2010; Fujita et al., 2011; Haynert et al., 2011; Uthicke et al., 2013). In contrast, some species showed no significant change of calcification under simulated future $p \mathrm{CO}_{2}$, whereas other species benefit from elevated $p \mathrm{CO}_{2}$ 
and showed an increase of growth (Vogel and Uthicke, 2012, McIntyre-Wressnig et al., 2013). Keul et al. (2013) revealed that not $p \mathrm{CO}_{2}$, but rather $\mathrm{CO}_{3}^{2-}$ is the parameter that affects the test size and weights of Ammonia tests. All these studies cultured living benthic foraminifera as isolated specimens without any natural sediment.

To date, no ocean acidification studies were reported to pursue culturing experiments with benthic foraminifera in their natural sedimentary environment. The field study of Haynert et al. (2012) in Flensburg Fjord exhibited that the carbonate chemistry of sediment pore water differed strongly from the conditions in the overlying near-bottom water. Sediment pore water $p \mathrm{CO}_{2}$ was constantly high, ranging from 1244 to $3324 \mu \mathrm{atm}$ during the entire year. Nevertheless, and as a consequence of higher alkalinity, $\Omega_{\text {calc }}$ was slightly supersaturated. Under these conditions, the composition and population density of the benthic foraminiferal community were not affected by seasonally elevated bottom water $p \mathrm{CO}_{2}$. Similar observations were described in the study of Kitidis et al. (2011), which showed that benthic ammonia oxidation rates in buffered sediments through $A_{\mathrm{T}}$ generation remained unaffected by ocean acidification in contrast to the overlying water column.

Benthic foraminifera are common in Kiel Fjord, western Baltic Sea, although seawater carbonate concentrations are permanently low and seasonally undersaturated with respect to $\Omega_{\text {calc }}$ (Thomsen et al., 2013). High biological activity and nutrient inputs characterize the area, and organic-rich mud prevails in Kiel Fjord (Nikulina et al., 2008). Degradation of organic matter between the sediment-water interface influences the underlying sediment chemistry (Graf et al., 1984), and therefore the habitat of benthic foraminifera. Benthic foraminifera in Kiel Fjord sediments were described in previous studies, initiated by Rhumbler (1935), followed by Rottgardt (1952), Lutze (1965), Wefer (1976), Nikulina et al. (2008) and Polovodova et al. (2008). These studies focused on taxonomy and distribution, and influences of temperature, salinity, oxygen, heavy metals and food supply, but did not consider possible impacts of seawater carbonate chemistry.

Kiel Fjord represents a suitable habitat to investigate the impact of natural high pore water $p \mathrm{CO}_{2}$ on benthic foraminifera, which prevail with high population densities in the southwestern Baltic Sea (Haynert et al., 2012). The aim of this study was to investigate the response of the life cycle (comprising population density, their growth and reproduction) and species composition by using a pristine assemblage from Kiel Fjord to constantly elevated $p \mathrm{CO}_{2}$ in their natural sedimentary environment during a long-term incubation over 6 months.

\section{Materials and methods}

\subsection{Field sampling}

Foraminiferal samples were collected from station KF1 $\left(54^{\circ} 20^{\prime} 713^{\prime \prime} \mathrm{N}, 10^{\circ} 10^{\prime} 160^{\prime \prime} \mathrm{E} ; 13 \mathrm{~m}\right.$ water depth) in Kiel Fjord, southwestern Baltic Sea, at the end of April 2011. At this location, the bottom sediment consists of silty fine sand. The sampling site was close to a previous sampling station PF15-13 of Polovodova and Schönfeld (2008), where Ammonia aomoriensis (synonymous to Ammonia beccarii of Nikulina et al. (2008) and Polovodova et al., 2009) is one of the dominating species in the living assemblage.

Surface sediment samples were taken with a Mini Muc K/MT 410 corer equipped with four tubes of $60 \mathrm{~cm}$ length and $10 \mathrm{~cm}$ inner diameter (Kuhn and Dunker, 1994), deployed from R/V Polarfuchs. Altogether, 24 cores were taken. A plastic ring marked with a centimeter-scale was used to slice off the uppermost $1 \mathrm{~cm}$ of the surface sediment (Schönfeld et al., 2012). On board, the surface sediment was first passed through a $2000 \mu \mathrm{m}$ screen in order to remove mollusk shells and pebbles. The samples were gently washed with seawater from Kiel Fjord. Surface sediment was transferred with a spoon into $300 \mathrm{~mL} \mathrm{Kautex}^{\mathrm{TM}}$ wide-neck containers and covered with bottom water taken from the supernatant water of the coring tubes. Kautex ${ }^{\mathrm{TM}}$ wide-neck containers were covered with Parafilm to avoid contamination by dust or evaporation. Afterwards, the samples were immediately brought to the laboratory at GEOMAR, where they were acclimated to culturing conditions at $17^{\circ} \mathrm{C}$ for 4 weeks.

\subsection{Preparation of culture vessels}

Stock cultures were aerated with compressed, humidified air and fed with $200 \mu \mathrm{L}$ DT's Premium Blend containing living algae of Nannochloropsis oculata, Phaeodactylum tricornutum and Chlorella once a week.

After 4 weeks of acclimation, the sediment material in the different Kautex ${ }^{\mathrm{TM}}$ wide-neck containers was combined in one plastic container. The seawater of the stock cultures was removed except for a few millimeters above the sediment surface. The sediment was homogenized with a spoon for a few minutes. This technique was a simple and gentle way to achieve an even distribution pattern of benthic foraminifera within the sediment. After homogenization in the plastic container, new culture vessels $(6.5 \times 6.5 \times 4.5 \mathrm{~cm})$ were used. Each culture vessel was filled with $0.4 \pm 0.1 \mathrm{~cm}$ of sediment layer by using a spoon-shaped plastic spatula. The measured sediment height was $0.36 \mathrm{~cm}$ on average, which results in a given culture vessel area of $42.25 \mathrm{~cm}^{2}$ in a mean sample volume of $15.2 \mathrm{~cm}^{3}$.

After spreading of the sediment, the culture vessels were transferred into the experimental setup and filled up with a $4 \mathrm{~cm}$ overlying seawater column, cartridge-filtered $(25 \mu \mathrm{m})$ from Kiel Fjord. For acclimatization and in order to restore 
the natural pore water chemistry in the sediments, the culture vessels were kept for 20 days at temperature of $17^{\circ} \mathrm{C}$ and a salinity of 16 until the start of the experiment. The acclimation of 20 days was deemed necessary to achieve a full recovery of the foraminiferal microhabitat pattern in a sub-centimeter scale (Ernst et al., 2002). During that time, $400 \mu \mathrm{L}$ DT's Premium Blend were added weekly into each culture vessel.

After 20 days of acclimation, a nepheloid detritus layer of $0.1 \mathrm{~cm}$ separated the seawater from the underlying sediment pore water. The resulting pore water stagnation equates to the conditions in their natural habitat, where foraminifera concentrate in the upper oxic surface layer of the sediment (Haynert et al., 2012). During field sampling we observed that the oxic sediment layer varied between 0.5 and $0.8 \mathrm{~cm}$.

\subsection{Experimental setup}

The culturing of benthic foraminiferal assemblages from Kiel Fjord was performed in a closed flow-through system modified after Hintz et al. (2004) and Haynert et al. (2011) (Fig. 1a). Each culture vessel was flushed with $25 \mu \mathrm{m}$ cartridge-filtered and UV-sterilized seawater from Kiel Fjord. The salinity values ranged from 15 to 16 during the experimental time. These relatively low salinities correspond to the natural conditions in the southwestern Baltic Sea. In comparison to the open oceans, this coastal region is characterized by low salinity (Wefer, 1976; Haynert et al., 2012). Observations from previous studies revealed that seawater salinity had no significant effect on change of diameter of Ammonia species, which inhabited hypo- to hypersaline waters (Bradshaw, 1957; Wefer, 1976; Haynert et al., 2012).

Four $p \mathrm{CO}_{2}$ levels were adjusted by aeration of $5 \mathrm{~L}$ compact jerrycans with compressed and $\mathrm{CO}_{2}$-enriched air (Fig. 1a). The target $p \mathrm{CO}_{2}$ levels were 380, 1120, 2400 and $4000 \mu \mathrm{atm}$. The simulated $p \mathrm{CO}_{2}$ levels equate to the environmental $p \mathrm{CO}_{2}$ conditions in the southwestern Baltic Sea. During the course of the year, $p \mathrm{CO}_{2}$ levels $>3000 \mu \mathrm{atm}$ can be observed (Haynert et al., 2012), and even higher levels are likely to occur in the future (Melzner et al., 2013). Therefore, the treatment levels are adjusted to the present variability in order to test future scenarios. Altogether, we prepared 84 culture vessels, three replicates for four $p \mathrm{CO}_{2}$ lines $(430,907$, 1865 and $3247 \mu \mathrm{atm}$ ), and combined seven subsamples per $p \mathrm{CO}_{2}$ treatment were terminated (Fig. 1b).

The preconditioned seawater from each tank flowed through the culture vessels, which were three times replicated for each $p \mathrm{CO}_{2}$ level (Fig. 1b). The overflow seeped through the fissure between lid and vessel, and drained off to a sink. The flow rate was adjusted to $0.16 \mathrm{~mL} \mathrm{~s}^{-1}$, which is sufficient to replace the water volume of the vessels 1.4 times per hour. The overflow drained off to a $60 \mathrm{~L}$ catchment tank. In the catchment tank, the water was sparged with compressed air at a high rate, in order to remove the excess $\mathrm{CO}_{2}$ before the water was pumped back to the compact jerrycans.
In order to avoid evaporation by aeration of the seawater with compressed and thus dry air, the gas was humidified in gaswashing bottles that were inserted in each compressed air connection. Evaporation of $1 \mathrm{~L}$ per week was compensated by refilling the system with deionized water. Food $(400 \mu \mathrm{L}$ DT's Premium Blend) was added to each culture vessel every week. The experiment was terminated after 6 months (Fig. 1b).

\subsection{Determination of water chemistry parameters}

Replicates (3n) of seawater $\mathrm{pH}_{\mathrm{NBS}}$ (National Bureau of Standards $\mathrm{pH}$ scale), temperature and salinity were determined with a WTW 340i pH analyzer and a WTW Cond 315i conductivity meter every week for four $p \mathrm{CO}_{2}$ treatments during 6 months of incubation time. The $\mathrm{pH}_{\mathrm{NBS}}$ electrode was calibrated with standard buffer solutions of $\mathrm{pH} 4.01,7.00$ and 10.00 (WTW standard, DIN/NIST buffers L7A). Precision was \pm 0.01 for $\mathrm{pH}_{N B S}$ and $\pm 0.1^{\circ} \mathrm{C}$ for temperature. The precision of the conductivity meter was \pm 0.1 salinity units.

Nutrient concentrations, phosphate $\left(\mathrm{PO}_{4}^{3-}\right)$ and silicate $(\mathrm{Si})$, were determined as duplicates (2n) monthly in one of the three replicates $(1 \mathrm{n})$ for each $p \mathrm{CO}_{2}$ level. Sterile-filtered $(0.2 \mu \mathrm{m}$ pore size $)$ nutrient samples were analyzed in colorimetrically in a spectrophotometer (U 2000, Hitachi Europe) at a wavelength of $882 \mathrm{~nm}$ and $810 \mathrm{~nm}$ according to Koroleff and Grasshof (1983). The measurement precision was $\pm 0.2 \mu \mathrm{mol} \mathrm{L}^{-1}$ for phosphate and, with reference to silicate concentrations, 2.5 to $6 \%$ for silicate.

Total dissolved inorganic carbon $\left(C_{\mathrm{T}}\right)$ was determined every month and analyzed in sterile-filtered $(0.2 \mu \mathrm{m}$ pore size $)$ water samples taken from one of the three replicates (1n) during the incubation time using an AIRICA autoanalyzer (Maranda $\mathrm{GmbH}$, Kiel, Germany) with a precision of 2$4 \mu \mathrm{mol} \mathrm{kg}{ }^{-1}$. The accuracy of the $C_{\mathrm{T}}$ measurements was ensured by using certified reference material provided by Andrew Dickson of the Scripps Institution of Oceanography (http://andrew.ucsd.edu/co2qc/).

Seawater carbonate system parameters $p \mathrm{CO}_{2}$, total alkalinity $\left(A_{\mathrm{T}}\right)$ and omega for calcite $\left(\Omega_{\text {calc }}\right)$ were calculated from $\mathrm{pH}_{\mathrm{NBS}}, C_{\mathrm{T}}$, temperature, salinity, $\mathrm{PO}_{4}^{3-}$ and $\mathrm{Si}$ values using CO2SYS software by Lewis and Wallace (1998). Dissociation constants $K_{1}$ and $K_{2}$ were chosen according to Mehrbach et al. (1973) as refitted by Dickson and Millero (1987) and $\mathrm{KHSO}_{4}$ dissociation constant after Dickson (1990).

After 6 months of incubation time, water chemistry parameters of $\mathrm{pH}_{\mathrm{NBS}}, A_{\mathrm{T}}$, temperature and salinity were measured and analyzed from the supernatant seawater and sediment pore water in one of the three replicates $(1 \mathrm{n})$ per $p \mathrm{CO}_{2}$ level. Seawater samples from $0-2 \mathrm{~cm}$ and $2-4 \mathrm{~cm}$ water layers were sterile-filtered $(0.2 \mu \mathrm{m}$ pore size $)$ and transferred directly into $20 \mathrm{~mL}$ PVC bottles. For sediment pore water analyses, the entire sediment samples were transferred into $50 \mathrm{~mL}$ centrifuge tubes and centrifuged at $3000 \mathrm{rpm}$ 


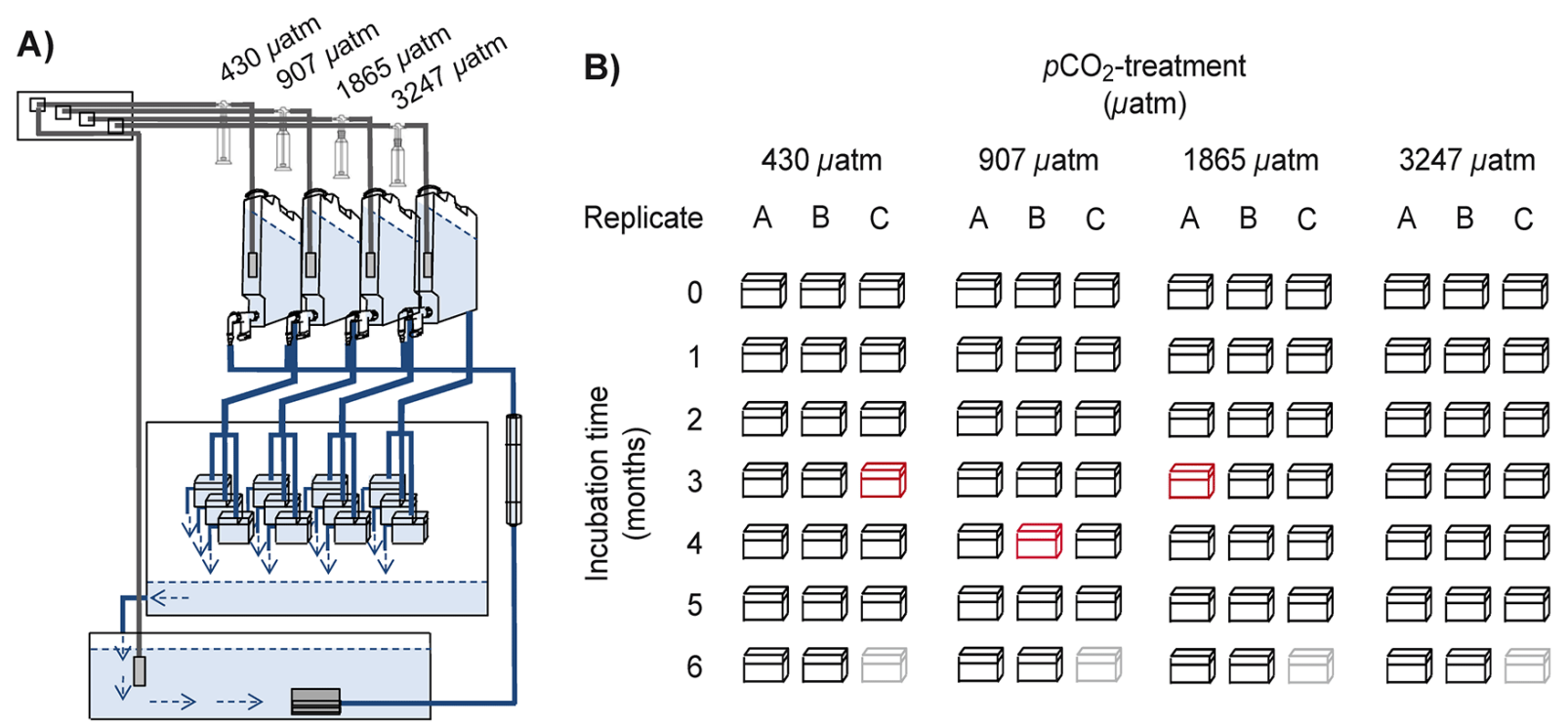

Fig. 1. (A) Scheme: experimental setup of A. aomoriensis in a closed flow-through system. Water equilibrated with four $p \mathrm{CO}_{2}$ levels $(430$, $907,1865$ and $3247 \mu \mathrm{atm})$ supplied from the compact jerrycans into the three replicated culture vessels and drained into a catchment tank, from where is was pumped up again to the jerrycans. (B) Experimental design: altogether 84 culture vessels, replication for four $p \mathrm{CO}_{2}$ treatments $(430,907,1865$ and $3247 \mu \mathrm{atm})$ during 6 months of incubation time. Red culture vessels: disappeared during incubation time. Culture vessels marked in light grey refer to treatments where carbonate chemistry parameters were measured in the supernatant seawater and sediment pore water in one of the three replicates after 6 months of incubation time.

for $15 \mathrm{~min}$ in order to separate the sediment pore water from the sediment. The extracted pore water was transferred through $0.2 \mu \mathrm{m}$ sterile filters into $20 \mathrm{~mL}$ PVC bottles. $\mathrm{pH}_{\mathrm{NBS}}$ and temperature were measured using the WTW $340 \mathrm{i} \mathrm{pH}$ analyzer; salinity was determined with WTW Cond $315 \mathrm{i}$ conductivity meter. Total alkalinity $\left(A_{\mathrm{T}}\right)$ was determined with a Metrohm titration instrument according to Ivanenkov and Lyakhin (1978). A greenish-brown methyl-red and methylene-blue indicator was added, and titration was performed with $0.02 \mathrm{M} \mathrm{HCl}$ and finished until a stable light pink color appeared. During titration, the sample was degassed by continuously bubbling argon through the solution in order to remove the generated $\mathrm{CO}_{2}$ or $\mathrm{H}_{2} \mathrm{~S}$. The measured values were standardized using an IAPSO seawater solution. The precision of the alkalinity measurements was $0.37 \%$. Carbonate parameters $p \mathrm{CO}_{2}, C_{\mathrm{T}}$ and $\Omega_{\text {calc }}$ of seawater and sediment pore water were calculated from measured $\mathrm{pH}_{\mathrm{NBS}}$, $A_{\mathrm{T}}$, temperature, salinity, $\mathrm{PO}_{4}^{3-}$ and $\mathrm{Si}$ values according to dissociation constants as specified above. Carbonate chemistry parameters were measured and calculated from seawater and sediment pore water for four $p \mathrm{CO}_{2}$ levels after 6-month incubation.

\subsection{Foraminiferal processing}

In order to monitor changes of the foraminiferal community during the incubation time, the sediment of three culture vessel replicates for each $p \mathrm{CO}_{2}$ line was analyzed monthly for foraminiferal assemblage composition. Due to the loss of some replicates during the incubation time (Fig. 1b), we added a replication (n) scheme for the measured parameters of population density or abundance, size class proportion, test diameter and $\mathrm{CaCO}_{3}$ weight of A. aomoriensis in Table 1 .

The complete benthic foraminiferal sediment samples were transferred from the culture vessels in $100 \mathrm{~mL} \mathrm{Kautex}^{\mathrm{TM}}$ wide-neck containers, preserved and stained with rose Bengal ethanol (94\%) solution of $2 \mathrm{~g} \mathrm{~L}^{-1}$ for 3 weeks following Lutze and Altenbach (1991). This period is sufficient to stain the protoplasm completely with rose Bengal in all tests of foraminifera (Schönfeld et al., 2012). Rose Bengal is an established and favorable method to discern between empty tests and living specimens. However, we would like to point out that staining with rose Bengal does not allow an accurate quantification of living and dead foraminifera (Bernhard et al., 2006). Stainable cytoplasm inside the tests is conserved for a long time; therefore it could be that the respective specimens had already terminated their metabolism. We have examined numerous examples from field and laboratory samples to be able to recognize the differences. A dead and altered protoplasm in Ammonia is orange instead of bright deep red and it shows no internal differentiation due to cell organelle. Nevertheless, we cannot rule out that population densities might be slightly overestimated in the current study (Bernhard et al., 2006).

Subsequently, the samples were gently washed with tap water through a $63 \mu \mathrm{m}$ sieve. The $63-2000 \mu \mathrm{m}$ and $>2000 \mu \mathrm{m}$ fractions were dried at $60^{\circ} \mathrm{C}$ for at least $24 \mathrm{~h}$. 
Table 1. Replication (n) scheme for the measured parameters of population density/abundance, size class proportion, test diameter and $\mathrm{CaCO}_{3}$ weight of Ammonia aomoriensis for four $p \mathrm{CO}_{2}$ treatments during 6 months of incubation time.

\begin{tabular}{llllllll}
\hline $\begin{array}{l}p \mathrm{CO}_{2-} \\
\text { treatment }\end{array}$ & \multicolumn{4}{c}{ Incubation time (months) } \\
\cline { 2 - 8 }$(\mu \mathrm{atm})$ & 0 & 1 & 2 & 3 & 4 & 5 & 6 \\
\hline 430 & $3 \mathrm{n}$ & $3 \mathrm{n}$ & $3 \mathrm{n}$ & $2 \mathrm{n}$ & $3 \mathrm{n}$ & $3 \mathrm{n}$ & $2 \mathrm{n}$ \\
907 & $3 \mathrm{n}$ & $3 \mathrm{n}$ & $3 \mathrm{n}$ & $3 \mathrm{n}$ & $2 \mathrm{n}$ & $3 \mathrm{n}$ & $2 \mathrm{n}$ \\
1865 & $3 \mathrm{n}$ & $3 \mathrm{n}$ & $3 \mathrm{n}$ & $2 \mathrm{n}$ & $3 \mathrm{n}$ & $3 \mathrm{n}$ & $2 \mathrm{n}$ \\
3247 & $3 \mathrm{n}$ & $3 \mathrm{n}$ & $3 \mathrm{n}$ & $3 \mathrm{n}$ & $3 \mathrm{n}$ & $3 \mathrm{n}$ & $2 \mathrm{n}$ \\
\hline
\end{tabular}

The size fraction $63-2000 \mu \mathrm{m}$ was picked completely for living and dead foraminifera. Samples were not split. All roseBengal-stained foraminifera were considered as living at the time of sampling, whereas unstained tests were considered as dead. Living and dead specimens were sorted by species. All species, except $A$. aomoriensis, were mounted in Plummer cell slides with glue, counted and measured using an eyepiece reticle on the Wild M3C dissecting microscope. A. aomoriensis was kept in single cell slides for further analyses.

Test morphometry of A. aomoriensis was analyzed with an automated image analysis system using a Leica Z16 APO microscope, and analySIS software (version 5.0) at the University of Angers, France (cf. Bollmann et al., 2004, Clayton et al., 2009). Resolution of images is $2.69 \mu \mathrm{m}^{2}$. Due to the oval shape of A. aomoriensis tests, the size of tests is given as mean diameter, calculated from the minimum and maximum diameter.

The $\mathrm{CaCO}_{3}$ weight of dead and living A. aomoriensis was measured using a micro-balance with an accuracy of $1 \mu \mathrm{g}$ (Sartorius, M3P-000V001). Finally, tests of corroded specimens of A. aomoriensis and Armorella sphaerica were photographed with a MiniPixie (MPX2051UC) digital microscope.

\subsection{Calculations}

The census data were standardized to population densities given as individuals/tests per $10 \mathrm{~cm}^{-3}$ sediment. Histograms were created depicting the proportion of living A. aomoriensis in 11 size classes from $<50$ to $>500 \mu \mathrm{m}$ at $50 \mu \mathrm{m}$ intervals and presented as the average of three replicates taken each month during the 6 months of incubation time.

$\mathrm{CaCO}_{3}$ weight per individual/test of $A$. aomoriensis was calculated from the total $\mathrm{CaCO}_{3}$ weight divided by the total number of individuals/tests. Carbonate production and accumulation of A. aomoriensis have been calculated from the difference of dry $\mathrm{CaCO}_{3}$ weight of individuals or tests produced or accumulated during 6 months of incubation time. The production or accumulation rate in grams refers to an area of $1 \mathrm{~m}^{2}$ per year.
From the control $p \mathrm{CO}_{2}$ line of $430 \mu \mathrm{atm}, 100$ living A. aomoriensis from size fraction 200 to $300 \mu \mathrm{m}$ were picked to calculate the total organic content, including cytoplasm and organic linings of the test, at the beginning of the experiment $(t=0)$ (Table S7 in the Supplement). The determination was performed by combustion off the organic material from the carbonate tests in a muffle furnace at $500^{\circ} \mathrm{C}$ for $6 \mathrm{~h}$. The amount of total organic content is calculated from the weight loss and given as a percentage of the total $\mathrm{CaCO}_{3}$ weight of the individuals (Table S8 in the Supplement). This value was subtracted from total weight to obtain the $\mathrm{CaCO}_{3}$ weight of shell carbonate in order to determine the absolute amount of $\mathrm{CaCO}_{3}$ production and accumulation (Table $\mathrm{S} 7 \mathrm{in}$ the Supplement).

\subsection{Statistics}

Data were tested for normality using Shapiro-Wilks test. Homogeneity of variances was analyzed by applying Levene's test. Parametric tests were conducted when the assumptions of normality and homogeneity were matched. The difference between initial abundances at $\mathrm{T} 0$ and $\mathrm{T} 1$ was compared by using Student'S $t$ tests for each $p \mathrm{CO}_{2}$ level. The relationship of test diameter and weight was tested by $\mathrm{AN}$ COVA with $p \mathrm{CO}_{2}$ as a categorical factor. A number of specimens collected during the experimental period (4-24 weeks) was analyzed for differences between $p \mathrm{CO}_{2}$ treatments using Kruskal-Wallis test, as data were not normally distributed. Similarly, differences between bulk water, bottom water and pore water were analyzed using Kruskal-Wallis test. Tests were carried out by using STATISTICA 8. ANOVA and regression analyses of test diameter and weights of living and dead A. aomoriensis were performed with StatView 4.02 ${ }^{\odot}$ Abacus Concepts Inc. All measured raw data of each treatment were used for statistical analyses.

\section{Results}

Water chemistry parameters, data set of population density or abundance, test diameter, test weight, and carbonate production or accumulation refers to means of the replicate measurements \pm standard deviation (SD). The culture vessels, from which carbonate chemistry of the supernatant seawater and sediment pore water have been determined after 6 months of incubation time, were excluded.

\subsection{Carbonate chemistry}

Seawater temperature and salinity were stable during the experimental period. Average temperatures ranged from $16.4 \pm 0.05$ to $17.2 \pm 0.27^{\circ} \mathrm{C}$ and salinities from $15.1 \pm 0.05$ to $15.9 \pm 0.30$ (Table 2).

Phosphate and silicate concentrations changed markedly over the course of the experiment. Phosphate concentration increased 31-fold during the first 3 months from $0.19 \pm 0.02$ 
Table 2. Carbonate chemistry parameters of each $p \mathrm{CO}_{2}$ treatment in the culture vessels. Total alkalinity $\left(A_{\mathrm{T}}\right)$, partial pressure of $\mathrm{CO}_{2}\left(p \mathrm{CO}_{2}\right)$ and saturation state of calcite $\left(\Omega_{\text {calc }}\right)$ were calculated from measured temperature, salinity, $\mathrm{pH}_{\mathrm{NBS}}$, total carbon $\left(C_{\mathrm{T}}\right)$, phosphate $\left(\mathrm{PO}_{4}^{3-}\right)$ and silicate $(\mathrm{Si})$. The $\mathrm{SD}(1 \sigma)$ refers to replicate measurements.

\begin{tabular}{|c|c|c|c|c|c|c|c|c|c|c|}
\hline \multirow{2}{*}{$\begin{array}{c}\quad p \mathrm{CO}_{2} \\
\text { values of gas } \\
\quad(\mu \mathrm{atm})\end{array}$} & \multirow{2}{*}{$\begin{array}{l}\text { Incubation } \\
\text { time } \\
\text { (months) }\end{array}$} & \multicolumn{6}{|c|}{ Seawater measurements } & \multicolumn{3}{|c|}{ Calculations from $\mathrm{pH}_{\mathrm{NBS}}$ and $C_{\mathrm{T}}$} \\
\hline & & $\begin{array}{c}T \\
\left({ }^{\circ} \mathrm{C}\right)\end{array}$ & $S$ & $\mathrm{pH}_{\mathrm{NBS}}$ & $\begin{array}{c}C_{\mathrm{T}} \\
\left(\mu \mathrm{mol} \mathrm{kg}{ }^{-1}\right)\end{array}$ & $\begin{array}{l}\mathrm{PO}_{4}^{3-} \\
\left(\mu \mathrm{mol} \mathrm{L}^{-1}\right)\end{array}$ & $\begin{array}{l}\mathrm{Si} \\
\left(\mu \mathrm{mol} \mathrm{L}^{-1}\right)\end{array}$ & $\begin{array}{c}A_{\mathrm{T}} \\
\left(\mu \mathrm{mol} \mathrm{kg}{ }^{-1}\right)\end{array}$ & $\begin{array}{l}p \mathrm{CO}_{2} \\
(\mu \mathrm{atm})\end{array}$ & $\Omega_{\text {calc }}$ \\
\hline \multirow{4}{*}{380} & 1 & $16.6 \pm 0.05$ & $15.8 \pm 0.04$ & $8.09 \pm 0.01$ & 2277.0 & $3.52 \pm 0.26$ & $262.17 \pm 1.11$ & 2422.5 & 472 & 3.30 \\
\hline & 2 & $16.4 \pm 0.05$ & $15.9 \pm 0.30$ & $8.01 \pm 0.01$ & 2276.5 & $5.87 \pm 0.10$ & $366.76 \pm 1.92$ & 2397.0 & 568 & 2.75 \\
\hline & 3 & $16.8 \pm 0.16$ & $15.5 \pm 0.04$ & $8.21 \pm 0.00$ & 2252.2 & $1.97 \pm 0.04$ & $144.35 \pm 2.04$ & 2439.8 & 352 & 4.23 \\
\hline & 4 & $17.2 \pm 0.24$ & $15.3 \pm 0.08$ & $8.13 \pm 0.01$ & 2250.6 & $1.60 \pm 0.01$ & $149.94 \pm 1.77$ & 2406.0 & 425 & 3.62 \\
\hline \multirow[t]{6}{*}{1120} & 0 & $16.8 \pm 0.04$ & $15.6 \pm 0.04$ & $7.87 \pm 0.02$ & 2420.0 & $0.18 \pm 0.01$ & $138.36 \pm 2.94$ & 2487.6 & 851 & 2.15 \\
\hline & 1 & $16.6 \pm 0.05$ & $15.8 \pm 0.04$ & $7.80 \pm 0.01$ & 2489.7 & $3.31 \pm 0.09$ & $261.87 \pm 1.22$ & 2545.5 & 1005 & 1.92 \\
\hline & 2 & $16.4 \pm 0.05$ & $15.8 \pm 0.04$ & $7.78 \pm 0.01$ & 2389.0 & $5.82 \pm 0.06$ & $367.33 \pm 0.67$ & 2439.6 & 1022 & 1.73 \\
\hline & 3 & $16.9 \pm 0.10$ & $15.5 \pm 0.04$ & $7.87 \pm 0.01$ & 2441.8 & $1.91 \pm 0.08$ & $148.48 \pm 8.29$ & 2514.6 & 842 & 2.22 \\
\hline & 4 & $16.7 \pm 0.14$ & $15.6 \pm 0.10$ & $7.83 \pm 0.02$ & 2335.5 & $1.68 \pm 0.17$ & $150.47 \pm 0.44$ & 2391.7 & 897 & 1.89 \\
\hline & 5 & $16.4 \pm 0.05$ & $15.2 \pm 0.05$ & $7.83 \pm 0.01$ & 2236.3 & $1.18 \pm 0.42$ & $139.61 \pm 0.14$ & 2286.9 & 867 & 1.77 \\
\hline \multirow[t]{7}{*}{2400} & 0 & $16.8 \pm 0.04$ & $15.6 \pm 0.04$ & $7.54 \pm 0.02$ & 2411.5 & $0.19 \pm 0.03$ & $140.00 \pm 3.76$ & 2389.7 & 1786 & 1.02 \\
\hline & 1 & $16.6 \pm 0.04$ & $15.8 \pm 0.00$ & $7.47 \pm 0.00$ & 2539.7 & $3.32 \pm 0.28$ & $261.57 \pm 1.75$ & 2499.0 & 2210 & 0.90 \\
\hline & 2 & $16.5 \pm 0.05$ & $15.8 \pm 0.04$ & $7.43 \pm 0.01$ & 2452.7 & $5.85 \pm 0.12$ & $368.11 \pm 0.50$ & 2404.9 & 2330 & 0.79 \\
\hline & 3 & $16.8 \pm 0.09$ & $15.5 \pm 0.04$ & $7.54 \pm 0.00$ & 2407.0 & $2.00 \pm 0.12$ & $149.52 \pm 8.27$ & 2385.3 & 1810 & 1.00 \\
\hline & 4 & $16.5 \pm 0.15$ & $15.3 \pm 0.10$ & $7.52 \pm 0.01$ & 2394.5 & $1.59 \pm 0.02$ & $150.12 \pm 0.79$ & 2365.7 & 1882 & 0.94 \\
\hline & 5 & $16.5 \pm 0.00$ & $15.2 \pm 0.05$ & $7.62 \pm 0.00$ & 2291.0 & $0.87 \pm 0.05$ & $140.33 \pm 0.38$ & 2289.0 & 1427 & 1.13 \\
\hline & 6 & $16.7 \pm 0.06$ & $15.2 \pm 0.06$ & $7.57 \pm 0.00$ & 2298.5 & 0.15 & 139.21 & 2283.5 & 1607 & 1.02 \\
\hline \multirow[t]{7}{*}{4000} & 0 & $16.8 \pm 0.05$ & $15.6 \pm 0.04$ & $7.32 \pm 0.04$ & 2496.5 & $0.21 \pm 0.02$ & $138.14 \pm 2.83$ & 2407.2 & 3031 & 0.63 \\
\hline & 1 & $16.6 \pm 0.05$ & $15.8 \pm 0.00$ & $7.31 \pm 0.01$ & 2564.9 & $3.79 \pm 0.32$ & $262.93 \pm 2.24$ & 2472.8 & 3179 & 0.63 \\
\hline & 2 & $16.4 \pm 0.05$ & $15.8 \pm 0.03$ & $7.17 \pm 0.01$ & 2492.9 & $5.90 \pm 0.17$ & $366.55 \pm 0.88$ & 2353.5 & 4178 & 0.43 \\
\hline & 3 & $16.6 \pm 0.05$ & $15.5 \pm 0.05$ & $7.34 \pm 0.00$ & 2573.5 & $2.12 \pm 0.33$ & $154.18 \pm 9.51$ & 2489.1 & 2983 & 0.67 \\
\hline & 4 & $17.1 \pm 0.34$ & $15.4 \pm 0.03$ & $7.30 \pm 0.02$ & 2461.2 & $1.59 \pm 0.03$ & $150.34 \pm 0.74$ & 2366.2 & 3178 & 0.59 \\
\hline & 5 & $16.5 \pm 0.05$ & $15.1 \pm 0.05$ & $7.32 \pm 0.01$ & 2327.4 & $1.07 \pm 0.04$ & $133.99 \pm 0.70$ & 2240.8 & 2870 & 0.56 \\
\hline & 6 & $16.6 \pm 0.06$ & $15.2 \pm 0.06$ & $7.25 \pm 0.01$ & 2332.8 & 0.17 & 136.62 & 2225.0 & 3310 & 0.49 \\
\hline
\end{tabular}

to $5.86 \pm 0.05 \mu \mathrm{mol} \mathrm{L}{ }^{-1}$ (Table 2). Mean silicate concentrations were in general high with $191.98 \pm 84.18 \mu \mathrm{mol} \mathrm{L}^{-1}$ and exhibited a threefold increase from $138.94 \pm 0.85$ to $367.19 \pm 0.69 \mu \mathrm{mol} \mathrm{L}^{-1}$ after 2 months (Table 2). Microscopic analysis showed that the detritus layer was composed of centric diatoms, which also dominated in the natural environment. By the end of the experiment, concentrations of phosphate and silicate decreased again and returned to the initial values that were observed at the beginning of the experiment.

As a consequence of four different $p \mathrm{CO}_{2}$ treatments, mean $\mathrm{pH}$ values ranged between $8.21 \pm 0.00$ and $7.17 \pm 0.01$ (Table 2) and were stable throughout the incubation period. Total inorganic carbon increased with increasing $p \mathrm{CO}_{2}$ from $2210.5 \pm 74.61$ to $2464.2 \pm 99.94 \mu \mathrm{mol} \mathrm{L}^{-1}$ (Table 2). The calculated mean $p \mathrm{CO}_{2}$ levels of the treatments were thereby $430 \pm 73.76,907 \pm 74.74,1865 \pm 317.19$ and $3247 \pm 435.51 \mu \mathrm{atm}$ (Table 2). It has to be noted that $\mathrm{CO}_{2}$ concentrations in the unchanged air effected a higher $p \mathrm{CO}_{2}$, while the partial pressures at higher concentrations led to markedly lower $p \mathrm{CO}_{2}$ levels than the target values. In the following, we refer our results to the $p \mathrm{CO}_{2}$ levels that prevailed in the culture vessels (Haynert et al., 2011). Mean seawater alkalinity was $2379.3 \pm 91.85 \mu \mathrm{mol} \mathrm{kg} \mathrm{kg}^{-1}$ and did not differ between the treatments (Table 2). At a $p \mathrm{CO}_{2}$ of $1865 \mu \mathrm{atm}$, seawater $\Omega_{\text {calc }}$ values decreased partially below 1. High $p \mathrm{CO}_{2}$ of $3247 \mu$ atm caused permanent undersaturation of $\Omega_{\text {calc }}$ with $0.57 \pm 0.09$ on average (Table 2 ).

During the experiment, a layer of organic detritus formed at the sediment-water interface. The carbonate chemistry measurements revealed strong differences of $p \mathrm{CO}_{2}$ and $\Omega_{\text {calc }}$ between seawater and sediment pore water in the culture vessels (Fig. 2). The sediment pore water was characterized by higher $p \mathrm{CO}_{2}$ and lower $\mathrm{pH}$ than the supernatant seawater in the culturing vessel (Fig. $2 \mathrm{a}$ and b). At the same time, pore water alkalinity $\left(3127.8 \pm 225.23 \mu \mathrm{mol} \mathrm{kg}^{-1}\right)$ was much higher than the bulk seawater alkalinity (0$2 \mathrm{~cm}$ water depths) of $2113.1 \pm 6.86 \mu \mathrm{mol} \mathrm{kg}^{-1}$ and the water overlaying the sediment $(2-4 \mathrm{~cm}$ water depths) with $2442.3 \pm 9.98 \mu_{\mathrm{mol} \mathrm{kg}}^{-1}$ (Kruskal-Wallis test, $H(2,12)=$ 9.85, $p<0.01$ ) (Table S1 in the Supplement). The accumulation of $A_{\mathrm{T}}$ in the sediment caused a relative high saturation of $\Omega_{\text {calc }}$ and even in the highest $p \mathrm{CO}_{2}$ treatment a slight supersaturation, $\Omega_{\text {calc }}>1$ (Fig. $2 \mathrm{c}$ and $\mathrm{d}$ ). 


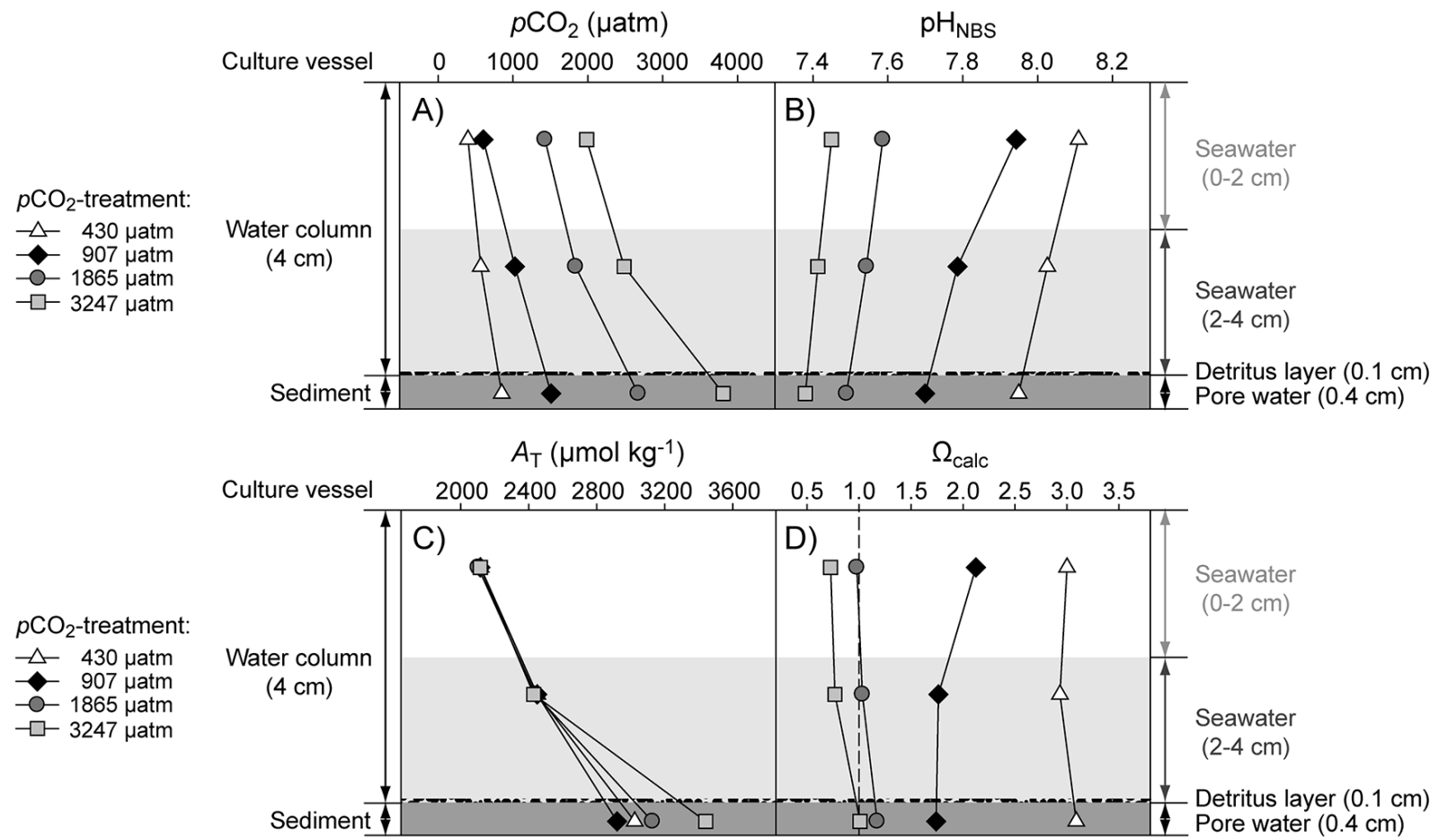

Fig. 2. Gradient of carbonate chemistry parameters of $(\mathbf{A})$ partial pressure of $\mathrm{CO}_{2}\left(p \mathrm{CO}_{2}\right),(\mathbf{B}) \mathrm{pH} \mathrm{NBS}_{\mathrm{NB}},(\mathbf{C})$ total alkalinity $\left(A_{\mathrm{T}}\right)$ and $(\mathbf{D})$ saturation state of calcite $\left(\Omega_{\text {calc }}\right)$ in the seawater and sediment pore water for four $p \mathrm{CO}_{2}$ treatments after 6 months of incubation time.

\subsection{Species composition and foraminiferal assemblages}

The assemblages comprised four calcareous species: Ammonia aomoriensis, the two subspecies Elphidium excavatum excavatum and Elphidium excavatum clavatum, as well as Elphidium gerthi and Elphidium incertum. Three arenaceous species were determined: Ammotium cassis, Reophax dentaliniformis and Armorella sphaerica (Tables 3 and 4).

The fauna was dominated by A. aomoriensis with $99 \%$ of the living fauna and $85 \%$ in the dead fauna, whereas $E$. incertum was rare with $1 \%$ of living individuals and $7 \%$ of dead tests (Tables 3 and 4 ). All other species were very rare or were only occasionally found in the foraminiferal assemblages. Accordingly, we will focus on the dominant calcareous species A. aomoriensis in the following.

\subsubsection{Population density and test diameter of living Ammonia aomoriensis}

The population density and size-frequency distribution exhibited strong variations due to growth and mortality of foraminiferal faunas during the 6 months of incubation (Tables S2, S3 and S4 and in the Supplement). Size distributions revealed growth, which was characterized by a similar increase of test diameter and the loss of individuals by death during the same period.

Initial population density $(t=0)$ of living A. aomoriensis fauna varied from 189 to 771 ind. $10 \mathrm{~cm}^{-3}$ with a mean of $433 \pm 166.16$ ind. $10 \mathrm{~cm}^{-3}$ (Table S3 in the Supplement). The initial test diameter $(t=0)$ ranged from $169 \pm 11.47$ to $182 \pm 3.52 \mu \mathrm{m}$, which equates to a mean diameter of $176 \pm 5.41 \mu \mathrm{m}$ (Table S4 in the Supplement). Whereas the population density at $430 \mu$ atm was relatively stable, the density fluctuated considerably in the 907,1865 and $3247 \mu$ atm $p \mathrm{CO}_{2}$ treatments (Fig. 3a). Ammonia aomoriensis density declined strongly during the first month at $p \mathrm{CO}_{2}$ of 1865 and $3247 \mu \mathrm{atm}$ (Fig. 3a). The reduction, however, was only significant at $1865 \mu \mathrm{atm}$ ( $t$ test, $p<0.05$ ). An explosive increase of living Ammonia aomoriensis up to $610 \pm 87.04$, $1378 \pm 22.78$ and $518 \pm 348.52$ ind. $10 \mathrm{~cm}^{-3}$ was observed at $p \mathrm{CO}_{2}$ of 907,1865 and $3247 \mu \mathrm{atm}$ after 3 months (Fig. 3a, Table S3 in the Supplement). A further increase up to $602 \pm 308.96$ ind. $10 \mathrm{~cm}^{-3}$ followed at $3247 \mu \mathrm{atm}$ after 5 months (Fig. 3a, Table S3 in the Supplement). Nevertheless, overall population densities did not significantly differ between the $p \mathrm{CO}_{2}$ levels, and densities of living foraminifera were not affected by treatment $p \mathrm{CO}_{2}$ after 5 months of incubation (Kruskal-Wallis test, $H(3,12)=$ $4.64, p>0.05)$. The strong increase of population densities correlated with the occurrence of high numbers of small individuals with a test diameter $<100 \mu \mathrm{m}$ at $p \mathrm{CO}_{2}$ of $1865 \mu \mathrm{atm}$ after 3 months, and at $p \mathrm{CO}_{2}$ of $3247 \mu \mathrm{atm}$ after 3 and 4 months (Fig. 4). A less pronounced occurrence of individuals $<100 \mu \mathrm{m}$ in the background was observed at a $p \mathrm{CO}_{2}$ of $907 \mu \mathrm{atm}$ after 4 and 5 months, though population densities were not affected (Fig. 4). 


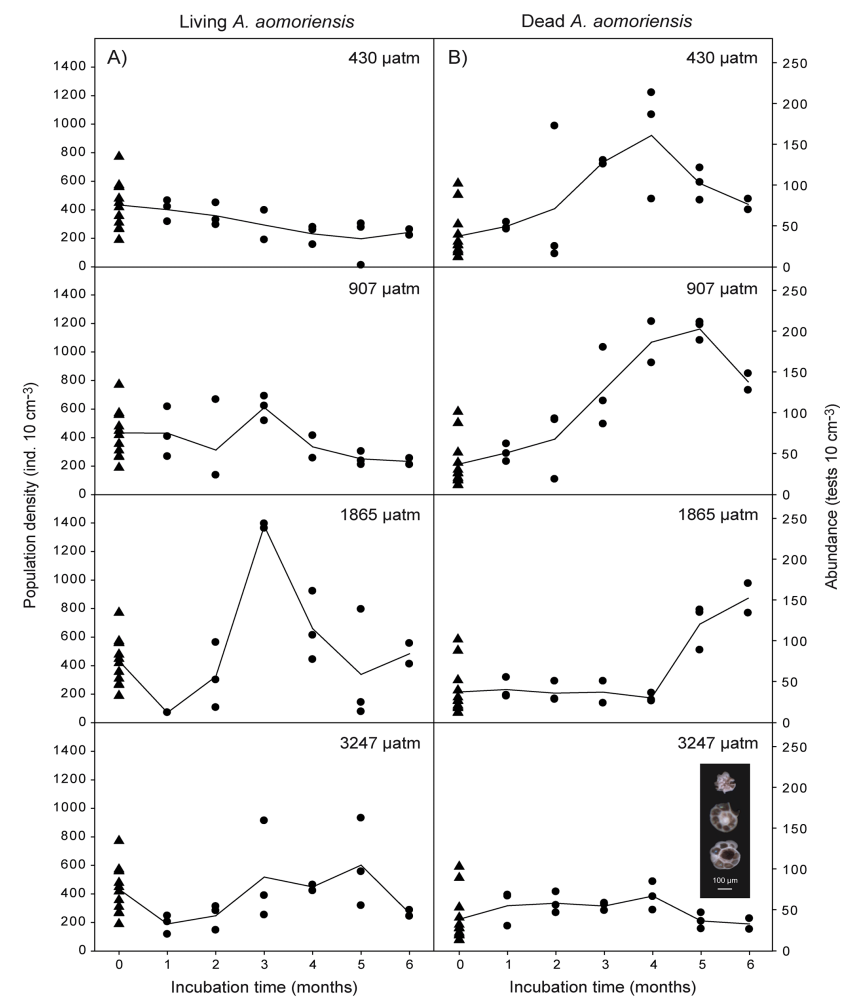

Fig. 3. (A) Population density of living and (B) abundance of dead A. aomoriensis at four $p \mathrm{CO}_{2}$ levels (430, 907, 1865 and $\left.3247 \mu \mathrm{atm}\right)$ during 6 months of incubation time. The triangles represent the initial population densities/abundances $(T=0)$. Circles represent population densities/abundances of the measured replicates during the incubation time. Continuous line refers to mean of the replicate measurements.

\subsubsection{Abundance and test diameter of dead Ammonia aomoriensis}

At the beginning of the experiment $(t=0)$, the mean abundance of the dead fauna was $38 \pm 29.37$ tests $10 \mathrm{~cm}^{-3}$, ranging from 13 to 103 tests $10 \mathrm{~cm}^{-3}$ (Table S5 in the Supplement). At $p \mathrm{CO}_{2}$ levels of 430 and $907 \mu \mathrm{atm}$, their abundance increased steadily until the fourth and fifth month, and subsequently decreased until the end of experiment (Fig. 3b). In contrast, at $p \mathrm{CO}_{2}$ of 1865 and $3247 \mu \mathrm{atm}$, the number of A. aomoriensis tests did not change until the fourth month (Fig. 3b). Afterwards, the number of empty tests increased by $80 \%$ at $1865 \mu \mathrm{atm}$ until the end of the experiment (Fig. 3b). These results correlated with a strong decline of population densities from $1378 \pm 22.78$ to $338 \pm 396.68$ ind. $10 \mathrm{~cm}^{-3}$ from the third to the fifth month (Fig. 3a, Table S4 in the Supplement). At $3247 \mu \mathrm{atm}$, test abundance decreased to $32 \pm 9.30$ tests $10 \mathrm{~cm}^{-3}$ at the end of the experiment $(H(3,12)=9.67, p=0.02)$ (Table S5 in the Supplement).

The mean test diameter ranged between $290 \pm 28.16$ and $283 \pm 32.50 \mu \mathrm{m}$ at $p \mathrm{CO}_{2}$ from 430 to $1865 \mu$ atm (Table S6 in the Supplement). At higher $p \mathrm{CO}_{2}$ of $3247 \mu \mathrm{atm}$, test di-

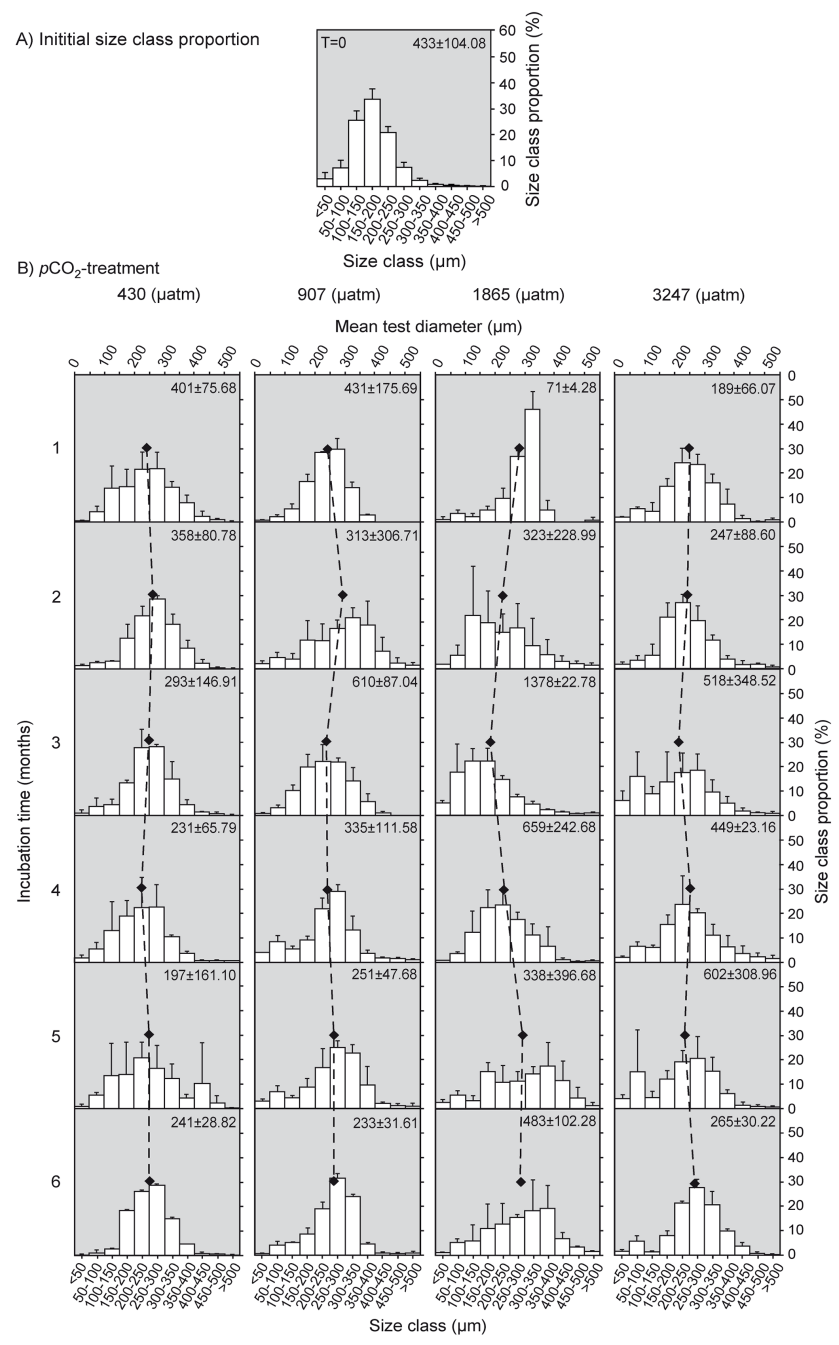

Fig. 4. Histogram of living A. aomoriensis, (A) initial size class proportions $(T=0)$ and $(\mathbf{B})$ size class proportions for the tested four $p \mathrm{CO}_{2}$ levels $(430,907,1865$ and $3247 \mu \mathrm{atm})$ during 6 months of incubation. Bars represent relative proportion of 11 size classes ranging from $<50$ until $>500 \mu \mathrm{m}$ in $50 \mu \mathrm{m}$ intervals. Mean test diameter (B) is displayed by the black diamonds and dashed lines. The number in each figure represents the mean population density $\pm \mathrm{SD}$, which refers to replicate measurements (Table S3 in the Supplement).

ameter was clearly lower with $258 \pm 51.66 \mu \mathrm{m}$, which indicated a frequent mortality of large and adult foraminifera up to $1865 \mu \mathrm{atm}$, whereas at higher $p \mathrm{CO}_{2}$ an increasing mortality of smaller and younger individuals was recognized (Table $\mathrm{S} 6$ in the Supplement). At high $p \mathrm{CO}_{2}$ of $3247 \mu \mathrm{atm}$, light micrograph images of dead A. aomoriensis showed that approximately $30 \%$ of the tests were completely destroyed during the last 2 months of the experiment. The strongest effect of test degradation was the characteristic star-like appearance, which left only the umbilicus area and the suture of the chambers intact (Fig. 3b). 


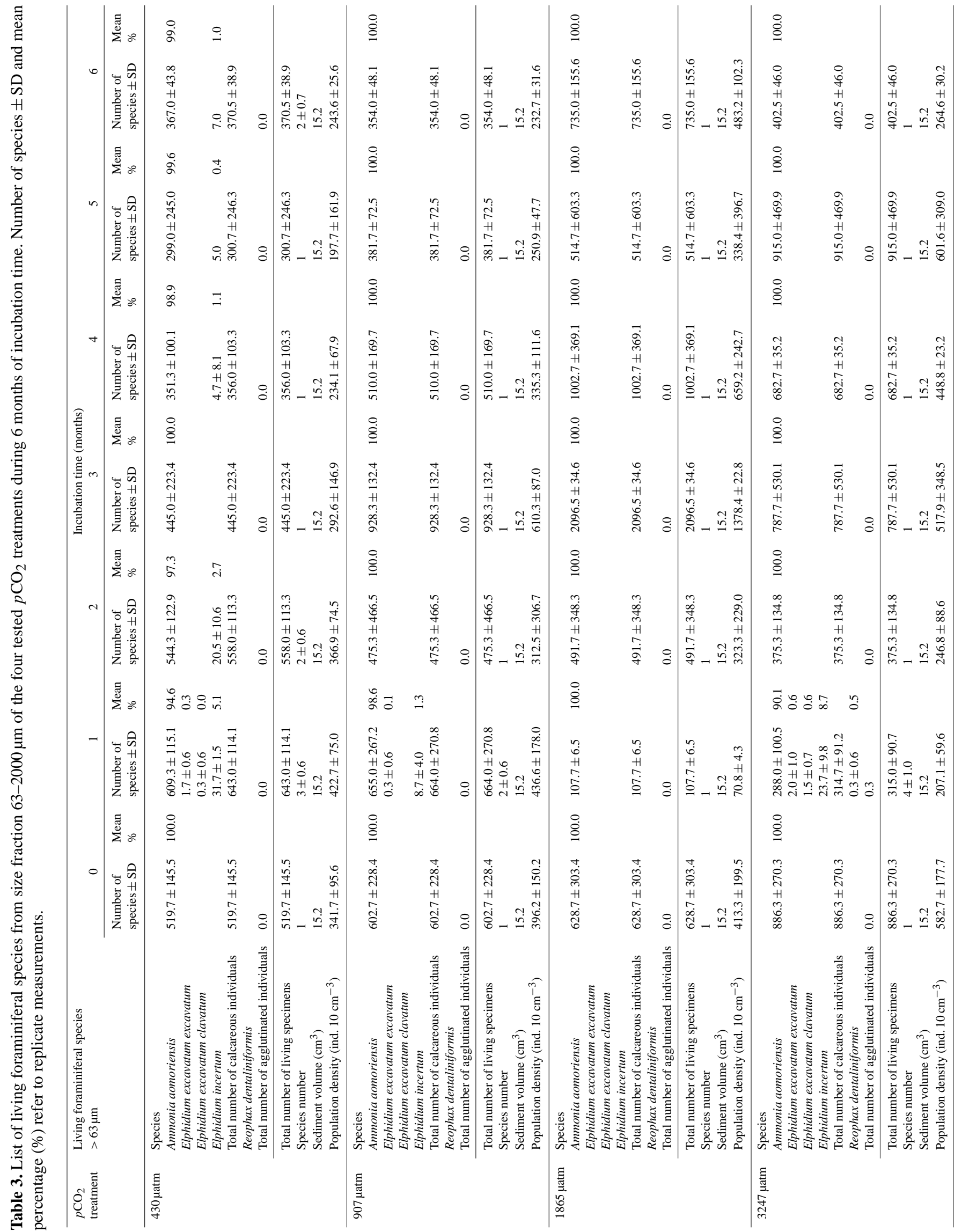




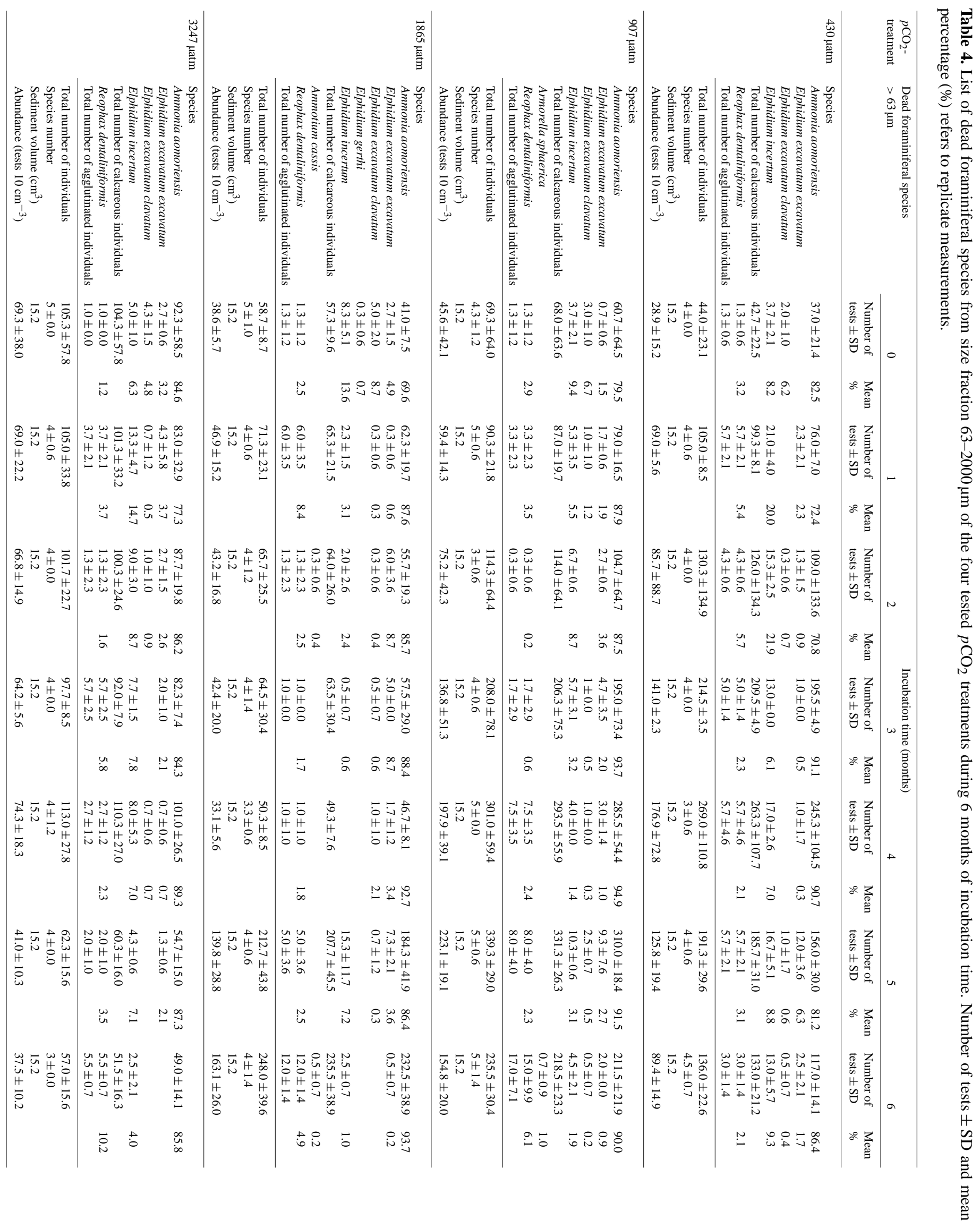




\section{3 $\mathrm{CaCO}_{3}$ weight of Ammonia aomoriensis}

The total organic content of living individuals was found to be $4.3 \%$, which is an average value measured from 100 individuals of a specific size ranging from 200 to $300 \mu \mathrm{m}$ (Table S7 in the Supplement). The total organic content of $4.3 \%$ was subtracted from total $\mathrm{CaCO}_{3}$ weight in order to determine the absolute amount of $\mathrm{CaCO}_{3}$ (cf. Movellan et al., 2012). The initial $\mathrm{CaCO}_{3}$ weight $(t=0)$ per individual of living A. aomoriensis was $1.56 \pm 0.40 \mu \mathrm{g}$ on average (Table S8 in the Supplement).

Test weight of living foraminifera was not affected by $p \mathrm{CO}_{2}$ treatment, but with increasing test diameter, the dry weight per living individual increased constantly (ANCOVA, factor test diameter: $F 117.3, p<0.01$, factor $p \mathrm{CO}_{2} F 1.0$, $p>0.05$ ) (Fig. 5a). Similar results were obtained for the relationship of dead tests (ANCOVA, factor test diameter: $F 17.6, p<0.01$, factor $p \mathrm{CO}_{2} F 0.34, p>0.05$ ). Earlier studies revealed an exponential relationship of foraminiferal size and weight due to their allometric growth (e.g., Altenbach, 1985; Schiebel and Movellan, 2012). Our data distribution showed only a slight curvature suggesting a quasilinear relationship in the measured size range. Indeed, the correlation coefficient of the exponential regression was with 0.94 only slightly higher as 0.91 of the linear regression applied to living A. aomoriensis data (Fig. 5a). However, $p$ value of the ANOVA table was $<0.0001$ in both cases suggesting the relationship between test diameter and weight can be described by a simple linear model with sufficient accuracy. The correlation coefficient of linear regression of mean test diameter and weights of living and dead specimens at the beginning, and after every month retrieved from the $4 p \mathrm{CO}_{2}$ treatments was $r=0.91$ and $r=0.59(n=28)$ (Fig. 5a and b). The $p$ value from the ANOVA table was $<0.0001$ and 0.0009 suggesting statistically significant relationships at the $>99.9 \%$ confidence level in both cases. With the exception of living specimens from the $430 \mu \mathrm{atm}$ treatment, regression line slopes and intercepts of individual $\mathrm{CO}_{2}$ levels were in the range of lower and upper $95 \%$ confidence intervals of the combined data set comprising all $\mathrm{CO}_{2}$ treatments (Fig. 5a). It has to be noted, however, that both correlation coefficients and $p$ values of the ANOVA tables were consistently lower in the data from empty tests. This pattern provides corroborating evidence that the relationship between mean test diameter and weights reliably displays the growth pattern of A. aomoriensis.

\subsection{Carbonate production and accumulation}

Production is considered as weight increase measured at subsequent sampling. Average production during the entire incubation period is given as mean value of monthly weight increases. Living A. aomoriensis exhibited the lowest mean $\mathrm{CaCO}_{3}$ production of $595 \pm 818 \mu \mathrm{g}$ at the lowest $p \mathrm{CO}_{2}$ of $430 \mu \mathrm{atm}$, followed by $886 \pm 728 \mu \mathrm{g}$ at the highest $p \mathrm{CO}_{2}$

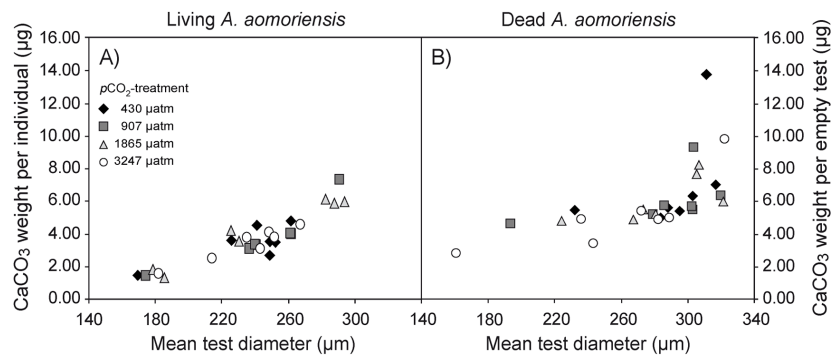

Fig. 5. Mean of total $\mathrm{CaCO}_{3}$ weight of (A) living specimens including cytoplasm and (B) empty test of $A$. aomoriensis in relation to mean test diameter for the four tested $p \mathrm{CO}_{2}$ treatments. Mean values refer to replicate measurements.

of $3247 \mu \mathrm{atm}$ after 6 months of incubation (Table S7 in the Supplement). The three replicate treatments of 907 and $1865 \mu \mathrm{atm}$ showed similarly higher mean $\mathrm{CaCO}_{3}$ production of $1269 \pm 821$ and $1256 \pm 1153 \mu \mathrm{g}$ with a total culture vessel area of $42.25 \mathrm{~cm}^{2}$ and an incubation time of 6 months (Table S8 in the Supplement). The calculated total carbonate production rate for living individuals was $0.47 \mathrm{~g} \mathrm{~m}^{-2} \mathrm{a}^{-1}$ (Table S7 in the Supplement).

The $\mathrm{CaCO}_{3}$ accumulation of empty tests varied between the $p \mathrm{CO}_{2}$ treatments. The highest rate of $908 \mu \mathrm{g} \mathrm{CaCO} 3$ was observed at $907 \mu \mathrm{atm}$, followed by $670 \mu \mathrm{g}$ at $430 \mu \mathrm{atm}$. With increasing $p \mathrm{CO}_{2}$ of 1865 and $3247 \mu \mathrm{atm}, \mathrm{CaCO}_{3}$ rates decline to 435 and $239 \mu \mathrm{g}$ after 6 months of incubation with the above specified settings. The calculated total carbonate accumulation of empty tests was $0.27 \mathrm{~g} \mathrm{~m}^{-2} \mathrm{a}^{-1}$ (Table $\mathrm{S} 7$ in the Supplement).

\section{Discussion}

\subsection{Sediment chemistry}

The sediment used in this experiment was from Kiel Fjord, western Baltic Sea, and is rich in organic matter (Nikulina et al., 2008). Organic substances influence the microbial activity, the rates and pathways of organic matter remineralization and nutrient recycling (Jonsson et al., 1990; Conley and Johnstone, 1995), and thereby influenced the underlying sediment chemistry (Graf et al., 1984). The remineralization of organic matter is mainly attributed to a wide array of hydrolytic and fermentative bacteria (Turley et al., 2000), which break complex multi-carbon compounds down to smaller, more soluble and digestible substances. Bacterial activity is often attributed as a limiting step in degradation of organic matter and extent of degradation (Tyson, 1995; Arnosti, 2004).

It is conceivable that silicate and phosphate concentrations were highly variable in the stagnated water body of the culture vessels throughout the experiment due to the high microbiological activity. Concentrations of both nutrients 
increased during the first 2 months and afterwards decreased until the end of the experiment.

One aspect could be the disturbance of the sediment after homogenization at the beginning of the experiment. This process could cause a remobilization of the bounded nutrients in the pore water, which diffused gradually through the filter of the nepheloid layer. This in turn would increase nutrient concentration increased in the overlying seawater.

The algal material of Nannochloropsis oculata, Phaeodactylum tricornutum and Chlorella added as food did not accumulate on the sediment surface. This in turn could imply that the added algae material was directly dissolved, which could explain the high silicate concentrations. Otherwise, increasing silicate concentrations may result from remineralization of diatoms (Conley and Johnstone, 1995). Sediment samples were taken in April, when high nutrient and productivity is usually encountered (Wulff et al., 1986; Elmgren, 1989; Wulff et al., 1990; Wollast, 1998; Thomas et al., 2003; Pätsch and Kühn, 2008). The spring bloom, ranging from the end of February to early April in the southwestern Baltic Sea, is dominated by diatoms, therefore maximal diatom biomass and biogenic silica flux to the sea floor (Wasmund et al., 2005, 2006). After deposition at the sediment surface, remineralization of the dead diatoms may have caused a substantial increase of silicate in the culture vessels during the experiment (Conley and Johnstone, 1995).

The high degradation of organic matter such as diatoms may have also caused an increase of phosphate concentrations (Balzer, 1986). In oxic sediments dissolved inorganic phosphate (DIP) is usually bound to calcium, chemisorbed by iron oxyhydroxides in distinct iron compounds and causes high phosphate accumulations in the sediment (Nissenbaum, 1979; Filipek and Owen, 1980; Krom and Berner, 1981). However, high $\mathrm{O}_{2}$ consumption by degradation of organic matter may have reduced the oxygen concentrations in the sediment, resulting in mobilization of DIP from sediments (Krom and Berner, 1981). The decrease of both nutrients until the end of the experiment may have arisen from bacterial microbiological activity of bacteria, although this aspect has not yet been sufficiently studied.

Degradation processes of organic matter at the sedimentwater interface consumed $\mathrm{O}_{2}$ and produced $\mathrm{CO}_{2}$, and thus resulted in higher sediment pore water $p \mathrm{CO}_{2}$ in comparison to the seawater. Similarly, the sediment was characterized by much higher alkalinity values than the seawater (3127 vs. $2379 \mu \mathrm{mol} \mathrm{kg}^{-1}$ ). Both aerobic or anaerobic degradation of organic matter release dissolved inorganic carbon (DIC). Whereas aerobic degradation has no effect, anaerobic degradation increases alkalinity $\left(A_{\mathrm{T}}\right)$ by denitrification and sulfate reduction (Yao and Millero, 1995; Thomas et al., 2009). Therefore, we assume that $\mathrm{O}_{2}$ consumption at the sedimentwater interface exceeded the delivery of $\mathrm{O}_{2}$ via diffusion, which could induce anaerobic conditions in the sediment pore water. The dark grey sediment color on the bottom of the culture vessels supported our assumption. This in turn enhances the $\mathrm{CO}_{2}$ buffer capacity and consequently causes a relatively high $\Omega_{\text {calc }}$ (Thomas et al., 2009). These differences of the carbonate chemistry between water column and sediment were in agreement with observations from field studies (Thomas et al., 2009; Kitidis et al., 2011; Haynert et al., 2012).

\subsection{Foraminiferal communities}

The species composition of living and dead assemblages, which were used in the experiment, were similar to the assemblages prevailing in Kiel and Flensburg fjords (Nikulina et al., 2008; Polovodova et al., 2008, 2009; Haynert et al., 2012). At the beginning of the experiment, the population density of the living fauna $\left(433 \pm 166.16\right.$ ind $\left.10 \mathrm{~cm}^{-3}\right)$ was very similar to the mean population density of 448 ind. $10 \mathrm{~cm}^{-3}$, found in the nearby sampling station PF15-13 in December 2005 (Nikulina et al., 2008; Polovodova et al., 2008). The living assemblages at both stations were dominated by A. aomoriensis (A. beccarii of Nikulina et al., 2008). In December 2005, E. excavatum clavatum was common and $E$. excavatum excavatum and $E$. incertum were rare; whereas in April 2011, the living fauna consisted almost exclusively of A. aomoriensis. These differences were probably caused by the interannual variation in the community structure (Lutze, 1974; Wefer, 1976; Polovodova et al., 2009; Haynert at al., 2012).

The dominance of living A. aomoriensis is probably explained by the diatom-dominated spring bloom, which enables high food supply and thereby facilitates foraminiferal growth in the southwestern Baltic Sea. This assumption is in agreement with a previous study, which reported that food supply plays an important role in relation to growth, chamber formation and reproduction of Ammonia species (Bradshaw, 1961). A similar relationship between diatom spring blooms and reproduction events was reported for E. excavatum clavatum at deeper waters off Boknis Eck, southwestern Baltic Sea (Schönfeld and Numberger, 2007).

In addition, the arenaceous species Armorella sphaerica occurred by incident in the setup (Fig. S1 in the Supplement. The species was recorded in Kiel Bay by Rhumbler (1935) and later by Brodniewicz (1965) in the southern Baltic Sea. Its sporadic occurrence and sudden appearance in our experiment could be explained by the activation of dormant propagules (Alve and Goldstein, 2002) or an erratically occurrence of juveniles or adults.

\subsection{Response of Ammonia aomoriensis life cycle}

In the first month of the experiment, population densities of living A. aomoriensis declined strongly at a $p \mathrm{CO}_{2}$ of 1865 and $3247 \mu \mathrm{atm}$. This decline might indicate conditions of $\Omega_{\text {calc }}<1$ in the sediment. The sediment was put in the vessels 20 days prior to $\mathrm{CO}_{2}$ manipulation. Nevertheless, the remineralization processes in the sediment were still ongoing 
as indicated by the strong increases of seawater phosphate and silicate concentration during the first 2 months. Therefore, high pore water alkalinity and thereby supersaturation of calcium carbonate might have not been established in the early phase of the experiment. Undersaturation has been already shown to decrease growth of A. aomoriensis and thereby increase mortality and test dissolution (Haynert et al., 2011). Similarly, a decrease of Ammonia species growth was observed with decreasing $\left[\mathrm{CO}_{3}^{2-}\right]$, respectively $\Omega_{\text {calc }}<1$ (Keul et al., 2013).

During the course of the experiment, however, the progressing remineralization processes in the sediment may have increased saturation state close to or even above 1. Accordingly, living A. aomoriensis specimens were relatively unaffected by high $p \mathrm{CO}_{2}$ later on and continued to grow, even under highly elevated $p \mathrm{CO}_{2}$ conditions (Haynert et al., 2012). The number empty shells declined under high $p \mathrm{CO}_{2}$, most probably as a result of dissolution due to slight undersaturation in the sediment pore water. Obviously, living foraminifera possess the ability to counteract moderate corrosion but dissolve under more severe undersaturation. Thus, high or low organic matter content of the substrate, grain size composition (Conley and Schelske, 1989), bacterial remineralization (Turley et al., 2000), and oxic or anoxic conditions (Jonsson et al., 1990) play a certain role in sediment and pore water chemistry, and thereby may influence the living conditions of benthic communities. In fine-grained sediments with a high content of organic substances, these processes could play an important role for the foraminiferal microhabitat. These observations are in agreement with the results of Kitidis et al. (2011), which showed that sediment ammonia oxidation rates, the key of microbial processes, were not affected by low $\mathrm{CO}_{2}$-acidified seawater, in sharp contrast to water column $\mathrm{NH}_{3}$ oxidation. They also suggested that buffering in sediments through $A_{\mathrm{T}}$ generation may explain the nonresponse to ocean acidification.

To date, no ocean acidification studies have been performed with benthic foraminifera in their natural sediment. In comparison, previous ocean acidification studies cultured living benthic foraminifera without their natural sediment (Le Cadre et al., 2003; Kuroyanagi et al., 2009; Dissard et al., 2010; Allison et al., 2010; Haynert et al., 2011; Fujita et al., 2011; Vogel and Uthicke, 2012; McIntyre-Wressnig et al., 2013; Keul et al., 2013). Under these laboratory conditions, foraminifera were directly exposed to the seawater, which might result in low and even undersaturation of omega calcite at high seawater $p \mathrm{CO}_{2}$ (Haynert et al., 2011). However, the mechanistic study of Keul et al. (2013), performed without any natural sediment, reported that not $p \mathrm{CO}_{2}$ but rather $\mathrm{CO}_{3}^{2-}$ is the parameter that affects the test size and weights of Ammonia species. The simulated high $p \mathrm{CO}_{2}$ levels between 829 and $1301 \mu \mathrm{atm}$ revealed simultaneously supersaturated $\Omega_{\text {calc }}$ ranging from 2.2 to 13.8 . Under these conditions, no or a very little impact of $p \mathrm{CO}_{2}$ was observed on the benthic foraminifera Ammonia.
Size distributions of tests may be explained by a combination of reproduction and mortality of individuals starting at a mean size of $285 \mu \mathrm{m}$ at a $p \mathrm{CO}_{2}$ ranging from 430 to $1865 \mu \mathrm{atm}$. At the highest $p \mathrm{CO}_{2}$ of $3247 \mu \mathrm{atm}$, mean test diameter was slightly lower with $258 \mu \mathrm{m}$. The size distribution revealed growth cohorts that were characterized by small, juvenile individuals $(<100 \mu \mathrm{m})$. Strong cohorts with high numbers of individuals $<100 \mu \mathrm{m}$ were observed at 1865 and $3247 \mu \mathrm{atm}$, with a strongest variability at $1865 \mu \mathrm{atm}$. According to the size-frequency distribution of a high number of small individuals, we assume that $A$. aomoriensis starts reproduction between a size of $250 \mu \mathrm{m}$ and $350 \mu \mathrm{m}$. At $350 \mu \mathrm{m}$, $40 \%$ of the growth cohorts either have produced juveniles or died. These results agreed with a previous study of Bradshaw (1957) where the mean test diameter of Streblus beccarii var. tepida ranged between 266 and $357 \mu \mathrm{m}$ at reproduction. In dependency of environmental conditions, reproduction follows approximately 28-day intervals with about 28 young juveniles per parent under optimal conditions (Bradshaw, 1957). In the current study, the different growth cohorts made it impossible to determine exactly either reproduction intervals or the number of juveniles per parent. However, the life cycle of A. aomoriensis has been insufficiently studied to date, and further field and laboratory experiments are necessary for a better understanding of the species-specific variability of Ammonia in general.

\subsection{Carbonate production of Ammonia aomoriensis}

The carbonate production of benthic foraminifera has been described in previous studies (e.g., Phleger and Soutar, 1973; Muller, 1974; Wefer and Lutze, 1978; Hallock, 1981; Bosence, 1989; Langer et al., 1997), which determined the foraminiferal carbonate content of sediment samples from different habitats. In contrast, in our study the main focus was on living benthic foraminifera containing cytoplasm. Little is known about the fractions of cytoplasm and test weight in benthic foraminifera. The estimated total organic content of living A. aomoriensis is $4.3 \%$ of total $\mathrm{CaCO}_{3}$ weight, which is in agreement with the estimated protein content of 20 and $5 \%$ organic dry content in Ammonia tepida (Movellan et al., 2012). The study of Wefer and Lutze (1976) observed a ratio of $1: 1$ of protoplasm and test weight in benthic foraminifera, which referred to wet weight (see Table 1 in Wefer and Lutze, 1976) The cytoplasm water content plays an important role in this determination as TEM micrograph images documented a high amount of seawater vacuoles in the foraminifera chambers (see Fig. A3.3.2 in Glock, 2011). Therefore, and in agreement with A. Movellan (personal communication, 2013), we assume a water content of approximately $76 \%$ in foraminiferal cytoplasm. However, the percentage of water and cytoplasm content varies in relation to test size and weight, and due to the natural variability of the microenvironment and the species-specific morphometry (Movellan et al., 2012). 
The carbonate production of living A. aomoriensis amounts to $0.47 \mathrm{~g} \mathrm{~m}^{-2} \mathrm{a}^{-1}$, whereas the carbonate accumulation of dead tests equates to $0.27 \mathrm{~g} \mathrm{~m}^{-2} \mathrm{a}^{-1}$ during the incubation time. This estimate of $\mathrm{CaCO}_{3}$ production is much higher than those reported for natural foraminiferal assemblages in the western Baltic Sea. Production rates of calcareous benthic foraminifera rates ranged from 0.01 to $0.03 \mathrm{~g} \mathrm{~m}^{-2} \mathrm{a}^{-1}$ in the shallow water habitat from 5 to $15 \mathrm{~m}$ depth of Kiel Bay (Wefer and Lutze, 1978). However, this low carbonate production was probably caused by a strong seasonality of food supply and mechanical stress on shoals with lag sediments, where these samples were taken. Muddy sediments such as in Kiel Fjord, with high organic matter content as potential source of food, showed a markedly higher foraminiferal carbonate production of up to $3.12 \mathrm{~g} \mathrm{~m}^{-2} \mathrm{a}^{-1}$ (Wefer and Lutze, 1978; Nikulina et al., 2008). Therefore, both favorable food supply and sustaining high population densities during the incubation facilitated the observed high $\mathrm{CaCO}_{3}$ productivity of A. aomoriensis.

No less than $36 \%$ of the produced tests are accumulated in the sediment, which is obviously higher than reported by Wefer and Lutze (1978); the accumulation rate ranged between 0 and $4 \%$ in the natural habitat. In the transitional environments from fine sand to mud, the accumulation rate varied from 1 to $1.2 \%$ (see Table 2 in Wefer and Lutze, 1978). Under natural conditions, mechanical forces play an important role and affected the tests, as well as dissolution and ingestion by macro- and meiofauna (Wefer and Lutze, 1978). In the present study, A. aomoriensis was cultivated in a protective habitat without any mechanical impacts of the empty tests and potential predators; therefore a higher accumulation rate was recorded.

\subsection{Dissolution features on foraminifera tests}

Living A. aomoriensis and E. incertum exhibited no dissolution features during the whole incubation time. These observations are in contrast to previous laboratory studies, where $A$. aomoriensis and $A$. beccarii exhibited a relationship between $p \mathrm{CO}_{2}$, respectively $\mathrm{pH}$, and test degradation (Le Cadre, 2003, Haynert et al., 2011). In comparison to the present study, living foraminifera were isolated from their natural sediment; therefore the tests of living specimens were directly affected by the carbonate chemistry conditions of the seawater. The conditions in the natural sediment create a protective microhabitat for benthic foraminifera with a relatively high calcium carbonate saturation state.

However, some empty tests of A. aomoriensis were destroyed at a $p \mathrm{CO}_{2}$ of $3247 \mu \mathrm{atm}$ during the last 2 months of incubation. This may be because high $p \mathrm{CO}_{2}$ and unfavorable $\Omega_{\text {calc }}<1$ reduced the average diameter. In contrast, empty tests of E. incertum showed no signs of dissolution. This species-specific response agrees well with our field observation from Flensburg Fjord (Haynert et al., 2012).

\section{Conclusions}

In the present ocean acidification study, benthic foraminifera were cultured in their natural sediment over a period of several generations. Under those laboratory conditions, the alkalinity $\left(A_{\mathrm{T}}\right)$ and therefore the $\mathrm{CO}_{2}$ buffer capacity in the sediment differed strongly from the conditions in the water column. Thereby the sediment chemistry created a microhabitat that supported the growth and development of a benthic foraminiferal community even at highly elevated $p \mathrm{CO}_{2}$. Fine-grained sediments with high organic matter content facilitated a high carbonate production of A. aomoriensis in the southwestern Baltic Sea. Growth and mortality of living A. aomoriensis were unaffected by elevated $p \mathrm{CO}_{2}$. Consequently, under the current microhabitat conditions, the dominant A. aomoriensis could maintain an important role in benthic carbonate production in the southwestern Baltic Sea. In contrast to the living fauna, approximately $30 \%$ of empty tests of $A$. aomoriensis were subjected to dissolution at high $p \mathrm{CO}_{2}$ of $3247 \mu$ atm and slight undersaturation of $\Omega_{\text {calc }}$, whereas empty $E$. incertum tests remained intact. These results emphasize the importance in understanding the sediment carbonate chemistry in the natural environment of benthic foraminifera, which depend on sediment type, grain size, organic matter, remineralization and chemical conditions in the pore water. In Kiel Fjord, organic-rich and fine-grained sediments prevail, which influences the pore water carbonate chemistry, and thereby provides a stable habitat for benthic foraminifera. Due to these characteristics, foraminiferal communities withstand present-day, seasonally high $p \mathrm{CO}_{2}$ levels and might also tolerate moderate future $p \mathrm{CO}_{2}$ increases.

\section{Supplementary material related to this article is available online at http://www.biogeosciences.net/11/ 1581/2014/bg-11-1581-2014-supplement.pdf.}

Acknowledgements. This study was funded by the German Research Foundation (grant SCHO605/7-1). The authors are grateful to the crew of R/V Polarfuchs for help with sampling in Kiel Fjord. We acknowledge Torben Struve for help with sampling and planning the design of experimental setup, Cara Nissen for supporting the water chemistry measurements, Gitta Ann von Roenn, Eva Klünker and Julia Langer for support during endless hours of picking. We thank Anna Jentzen (GEOMAR) for help with the automatic analysis measurements at the University of Angers. Martin Wahl (GEOMAR) and Ulf Riebesell (GEOMAR) provided the climate room and laboratory facilities during experimental time. We gratefully acknowledge the encouragement and advice of four anonymous reviewers and Vasilis Kitidis, which improved our paper.

The service charges for this open access publication have been covered by a Research Centre of the Helmholtz Association.

Edited by: E. Marañón 


\section{References}

Allison, N., Austin, W., Paterson, D., and Austin, H.: Culture studies of the benthic foraminifera Elphidium williamsoni: Evaluating $\mathrm{pH}, \Delta\left[\mathrm{CO}_{3}^{2-}\right]$ and inter-individual effects on test $\mathrm{Mg} / \mathrm{Ca}$, Chem. Geol., 274, 87-93, 2010.

Altenbach, A. V.: Die Biomasse der benthischen Foraminiferen, Ph.D. Thesis, Kiel University, 167 pp., 1985.

Alve, E. and Goldstein, S. T.: Resting stage in benthic foraminiferal propagules: a key feature for dispersal? Evidence from two shallow-water species, J. Micropaleontol., 21, 95-96, 2002.

Arnosti, C.: Speed bumps and barricades in the carbon cycle: substrate structural effects on carbon cycling, Mar. Chem., 92, 263273, 2004.

Balzer, W.: Forms of phosphorus and its accumulation in coastal sediments of Kieler Bucht, Ophelia, 26, 19-35, 1986.

Bernhard, J. M., Ostermann, D. R., Williams, D. S., and Blanks, J. K.: Comparison of two methods to identify live benthic foraminifera: A test between Rose Bengal and CellTracker Green with implications for stable isotope paleoreconstructions, Paleoceanography, 21, PA4210, doi:10.1029/2006PA001290, 2006.

Bollmann, J., Quinn, P., Vela, M., Brabec, B., Brechner, S., Cortés, M. Y., Hilbrecht, H., Schmidt, D. N., Schiebel, R., Hans, R., and Thierstein, H. R.: Automated Particle Analysis: Calcareous Microfossils, Image Analysis, Sediments and Paleoenvironments, Dev. Paleoenviron. Res., 7, 229-252, 2004.

Bosence, D.: Biogenic Carbonate Production in Florida Bay, Bull. Mar. Sci., 4, 419-433, 1989.

Bradshaw, J. S.: Laboratory studies on the rate of growth of the foraminifer, "Streblus beccarii (Linné) var. tepida (Cushman)", J. Paleontol., 31, 1138-1147, 1957.

Bradshaw, J. S.: Laboratory experiments on the ecology of foraminifera, Contributions from the Cushman Foundation for foraminiferal research, XII (part 3), 87-106, 1961.

Brodniewicz, I.: Recent and some Holocene Foraminifera of the southern Baltic Sea, Acta Palaeontol. Pol., 10, 131-226, 1965.

Clayton, C. R. I, Abbireddy, C. O. R., and Schiebel, R.: A method of estimating the form of coarse particulates, Rev. Fr. Geotech., 59, 493-501, 2009.

Conley, D. J. and Johnstone, R. W.: Biogeochemistry of N, P and Si in Baltic Sea sediments: response to a simulated deposition of a spring bloom, Mar. Ecol.-Prog. Ser., 122, 265-276, 1995.

Conley, D. J. and Schelske, C. L.: Processes controlling the benthic regeneration and sedimentary accumulation of biogenic silica in Lake Michigan, Arch. Hydrobiol., 116, 23-43, 1989.

Corliss, B. H.: Microhabitats of benthic foraminifera within deepsea sediments, Nature, 314, 435-438, 1985.

Dickson, A. G.: Standard potential of the reaction $\mathrm{AgCl}(\mathrm{s})+\frac{1}{2} \mathrm{H}_{2}(\mathrm{~g})=\mathrm{Ag}(\mathrm{s})+\mathrm{HCl}(\mathrm{aq})$ and the standard acidity constant of the ion $\mathrm{HSO}_{4}^{-}$in synthetic sea-water from 273.15 K to 318.15 K, J. Chem. Thermodyn., 22, 113-127, 1990.

Dickson, A. G. and Millero, F. J.: A comparison of the equilibrium constants for the dissociation of carbonic acid in seawater media, Deep-Sea Res., 34, 1733-1743, 1987.

Dissard, D., Nehrke, G., Reichart, G. J., and Bijma, J.: Impact of seawater $p \mathrm{CO}_{2}$ on calcification and $\mathrm{Mg} / \mathrm{Ca}$ and $\mathrm{Sr} / \mathrm{Ca}$ ratios in benthic foraminifera calcite: results from culturing experiments with Ammonia tepida, Biogeosciences, 7, 81-93, doi:10.5194/bg-7-81-2010, 2010.
Elmgren, R.: Man's impact on the ecosystem of the Baltic Sea: energy flows today and at the turn of the century, Ambio, 18, 326332, 1989.

Ernst, S., Duijnstee, I., and van der Zwaan, B.: The dynamics of the benthic foraminiferal microhabitat: recovery after experimental disturbance, Mar. Micropaleontol., 46, 343-361, 2002.

Filipek, L. H. and Owen, R. M.: Diagenetic controls of phosphorus in outer continental shelf sediments from Gulf of Mexico, Chem. Geol., 33, 181-204, 1980.

Fujita, K., Hikami, M., Suzuki, A., Kuroyanagi, A., Sakai, K., Kawahata, H., and Nojiri, Y.: Effects of ocean acidification on calcification of symbiont-bearing reef foraminifers, Biogeosciences, 8, 2089-2098, doi:10.5194/bg-8-2089-2011, 2011.

Glock, N.: Benthic foraminifera as geochemical and micropaleontological proxies for redox conditions in the Peruvian oxygen minimum zone (dissertation), Christian-Albrechts-Universität Kiel, Kiel, Germany, urn:nbn:de:gbv:8-diss-69182, 137 pp., 2011.

Graf, G., Bengtsson, W., Faubel, L., Meyer-Reil, L., Schulz, R., Theede, H., and Thiel, H.: The importance of the spring phytoplankton bloom for the benthic system of Kiel Bight, Rapports et Proces-verbaux des Réunions, Conseil International pour l'Éxploration de la Mer, 183, 136-143, 1984.

Hallock, P.: Production of carbonate sediments by selected large benthic foraminifera on two pacific coral reefs, J. Sediment. Petrol., 51, 467-474, 1981.

Haynert, K., Schönfeld, J., Riebesell, U., and Polovodova, I.: Biometry and dissolution features of the benthic foraminifer Ammonia aomoriensis at high $p \mathrm{CO}_{2}$, Mar. Ecol.-Prog. Ser., 432, 53-67, doi:10.3354/meps09138, 2011.

Haynert, K., Schönfeld, J., Polovodova-Asteman, I., and Thomsen, $\mathrm{J} .:$ The benthic foraminiferal community in a naturally $\mathrm{CO}_{2}$-rich coastal habitat of the southwestern Baltic Sea, Biogeosciences, 9, 4421-4440, doi:10.5194/bg-9-4421-2012, 2012.

Heron-Allen, E. and Earland, A.: Foraminifera. Part I: The Ice-free area of the Falkland Island and adjacent seas, Disc. Rep., 4, 291460, 1932.

Hintz, C. J., Chandler, G. T., Bernhard, J. M., McCorkle, D. C., Havach, S. M., Blanks, J. K., and Shaw, T. J.: A physicochemically constrained seawater culturing system for production of benthic foraminifera, Limnol. Oceanogr.-Methods, 2, 160-170, doi:10.4319/lom.2004.2.160, 2004.

Höglund, H.: Foraminifera of the Gullmar Fjord and the Skagerak, Zoologiska Bidrag Fran Uppsala, 26, 1-328, 1947.

Ivanenkov, V. N. and Lyakhin, Y. I.: Determination of total alkalinity in seawater, in: Methods of Hydrochemical Investigations in the Ocean, edited by: Borodovsky, O. K. and Ivanenkov, V. N., Nauka, Moscow, 110-114, 1978.

Jonsson, P., Carman, R., and Wulff, F.: Laminated sediments in the Baltic - a tool for evaluating nutrient mass balances, Ambio, 19, 152-158, 1990.

Keul, N., Langer, G., de Nooijer, L. J., and Bijma, J.: Effect of ocean acidification on the benthic foraminifera Ammonia sp. is caused by a decrease in carbonate ion concentration, Biogeosciences, 10, 6185-6198, doi:10.5194/bg-10-6185-2013, 2013.

Kitidis, V., Laverock, B., McNeill, L. C., Beesley, A., Cummings, D., Tait, K., Osborn, M. A., and Widdicombe, S.: Impact of ocean acidification on benthic and water column ammonia oxidation, Geophys. Res. Lett., 38, L21603, doi:10.1029/2011GL049095, 2011. 
Koroleff, F. and Grasshoff, K.: Determination of nutrients, in: Methods of seawater analysis, edited by: Grasshoff, K., Ehrhardt, M., and Kremling, K., Verlag Chemie, Weinheim, 419 pp., 1983.

Krom, M. D. and Berner, R. A.: The diagenesis of phosphorus in a nearshore marine sediment, Geochim. Cosmochim. Ac., 45, 207-216, 1980.

Kuhn, G. and Dunker, E.: Der Minicorer, ein Gerät zur Beprobung der Sediment/Bodenwasser-Grenze, Greifswalder Geowissenschaftliche Beiträge, 2, 99-100, 1994.

Kuroyanagi, A., Kawahata, H., Suzuki, A., Fujita, K., and Irie, T.: Impacts of ocean acidification on large benthic foraminifers: results from laboratory experiments, Mar. Micropaleontol., 73, 190-195, 2009.

Langer, M. R., Silk, M. T., and Lipps, J. H.: Global ocean carbonate and carbon dioxide production: the role of reef foraminifera, $\mathrm{J}$. Foraminiferal. Res., 27, 271-277, 1997.

Le Cadre, V., Debenay, J. P., and Lesourd, M.: Low pH effects on Ammonia beccarii test deformation: implications for using test deformations as a pollution indicator, J. Foraminiferal. Res., 33, $1-9,2003$.

Lewis, E. and Wallace, D. W. R.: Program developed for $\mathrm{CO}_{2}$ system calculations, Oak Ridge, Oak Ridge National Laboratory ORNL/CDIAC, Oak Ridge, 105, 1998.

Lutze, G. F.: Zur Foraminiferen-Fauna der Ostsee, Meyniana, 15, 75-142, 1965.

Lutze, G. F.: Foraminiferen der Kieler Bucht (Westliche Ostsee): 1. "Hausgartengebiet" des Sonderforschungsbereiches 95 der Universität Kiel, Meyniana, 26, 9-22, 1974.

Lutze, G. F. and Altenbach, A.: Technik und Signifikanz der Lebendfärbung benthischer Foraminiferen mit Bengalrot, Geologisches Jahrbuch, A128, 251-265, 1991.

McIntyre-Wressnig, A., Bernhard, J. M., McCorkle, D. C., and Hallock, P.: Non-lethal effects of ocean acidification on the symbiont-bearing benthic foraminifer Amphistegina gibbosa, Mar. Ecol.-Prog. Ser., 472, 45-60, doi:10.3354/meps09918, 2013.

Mehrbach, C., Culberso, C. H., Hawley, J. E., and Pytkowic, R. W.: Measurement of the apparent dissociation-constants of carbonic acid in seawater at atmospheric-pressure, Limnol. Oceanogr., 18, 897-907, 1973.

Melzner, F., Thomsen, J., Koeve, W., Oschlies, A., Gutowska, M. A., Bange, H. W., Hansen, H. P., and Körtzinger, A.: Future ocean acidification will be amplified by hypoxia in coastal habitats, Mar. Biol., 160, 1875-1888, doi:10.1007/s00227-012-1954$1,2013$.

Movellan, A., Schiebel, R., Zubkov, M. V., Smyth, A., and Howa, H.: Protein biomass quantification of unbroken individual foraminifers using nano-spectrophotometry, Biogeosciences, 9, 3613-3623, doi:10.5194/bg-9-3613-2012, 2012.

Muller Hallock, P.: Sediment Production and Population Biology of the Benthic Foraminifer Amphistegina madagascariensis, Limnol. Oceanogr., 19, 802-809, 1974.

Nikulina, A., Polovodova, I., and Schönfeld, J.: Foraminiferal response to environmental changes in Kiel Fjord, SW Baltic Sea, Earth (Waukesha), 3, 37-49, 2008.

Nissenbaum, A.: Phosphorus in marine and non-marine humic substances, Geochim. Cosmochim. Ac., 43, 1973-1978, 1979.
Pätsch, J. and Kühn, W.: Nitrogen and carbon cycling in the North Sea and exchange with the North Atlantic - a model study Part I: Nitrogen budget and fuxes, Cont. Shelf Res., 28, 767-787, 2008.

Phleger, F. B. and Soutar, A.: Production of Benthic Foraminifera in Three East Pacific Oxygen Minima, Micropaleontology, 19, 110-115, 1973.

Polovodova, I. and Schönfeld, J.: Foraminiferal test abnormalities in the western Baltic Sea, J. Foraminiferal. Res., 38, 318-336, 2008.

Polovodova, I., Nikulina, A., Schönfeld, J., and Dullo, W. C.: Recent benthic foraminifera in the Flensburg Fjord, J. Micropaleontol., 28, 131-142, 2009.

Rhumbler, L.: Rhizopoden der Kieler Bucht, gesammelt durch A. Remane, I. Teil, Schriften des Naturwissenschaftlichen Vereins Schleswig-Holstein, 21, 143-194, 1935.

Rottgardt, D.: Mikropaläontolgische wichtige Bestandteile rezenter brackischer Sedimente an den Küsten Schlewig-Holsteins, Meyniana, 1, 169-228, 1952.

Schiebel, R. and Movellan, A.: First-order estimate of the planktic foraminifer biomass in the modern ocean, Earth Syst. Sci. Data, 4, 75-89, doi:10.5194/essd-4-75-2012, 2012.

Schönfeld, J. and Numberger, L.: The benthic foraminiferal response to the 2004 spring bloom in the western Baltic Sea, Mar Micropaleontol., 65, 78-95, 2007.

Schönfeld, J., Alve, E., Geslin, E., Jorissen, F., Korsun, S., Spezzaferri, S., Abramovich, S., Almogi-Labin, A., Armynot du Chatelet, E., Barras, C., Bergamin, L., Bicchi, E., Bouchet, V., Cearreta, A., Di Bella, L., Dijkstra, N., Trevisan Disaro, S., Ferraro, L., Frontalini, F., Gennari, G., Golikova, E., Haynert, K., Hess, S., Husum, K., Martins, V., McGann, M., Oron, S., Romano, E., Mello Sousa, S., and Tsujimoto A.: The FOBIMO (FOraminiferal BIo-MOnitoring) initiative-Towards a standardized protocol for soft-bottom benthic foraminiferal monitoring studies, Mar. Micropaleontol., 94-95, 1-13, 2012.

Thomas, H., Pempkowiak, J., Wulff, F., and Nagel, K.: Autotrophy, nitrogen accumulation and nitrogen limitation in the Baltic Sea: a paradox or a buffer for eutrophication?, Geophys. Res. Lett., 30, 2130, doi:10.1029/2003GL017937, 2003.

Thomas, H., Schiettecatte, L.-S., Suykens, K., Koné, Y. J. M., Shadwick, E. H., Prowe, A. E. F., Bozec, Y., de Baar, H. J. W., and Borges, A. V.: Enhanced ocean carbon storage from anaerobic alkalinity generation in coastal sediments, Biogeosciences, 6, 267274, doi:10.5194/bg-6-267-2009, 2009.

Thomsen, J., Gutowska, M. A., Saphörster, J., Heinemann, A., Trübenbach, K., Fietzke, J., Hiebenthal, C., Eisenhauer, A., Körtzinger, A., Wahl, M., and Melzner, F.: Calcifying invertebrates succeed in a naturally $\mathrm{CO}_{2}$-rich coastal habitat but are threatened by high levels of future acidification, Biogeosciences, 7, 3879-3891, doi:10.5194/bg-7-3879-2010, 2010.

Thomsen, J., Casties, I., Pansch, C., Körtzinger, A., and Melzner, F.: Food availability outweighs ocean acidification effects in juvenile Mytilus edulis: laboratory and field experiments, Glob. Change Biol., 19, 1017-1027, doi:10.1111/gcb.12109, 2013.

Turley, C. M., Bianchi, M., Christaki, U., Conan, P., Harris, J. R. W., Psarra, S., Ruddy, G., Stutt, E. D., Tselepides, A., and Van Wambeke, F.: Relationship between primary producers and bacteria in an oligotrophic sea - the Mediterranean and biogeochemical implications, Mar. Ecol.-Prog. Ser., 193, 11-18, 2000. 
Tyson, R. V.: Sedimentary Organic Matter - Organic Facies and Palynofacies, Chapman \& Hall, London, 1995.

Uthicke, S., Momigliano, P., and Fabricius, K. E.: High risk of extinction of benthic foraminifera in this century due to ocean acidification, Sci. Rep., 3, 1769, doi:10.1038/srep01769, 2013.

Vogel, N. and Uthicke, S.: Calcification and photobiology in symbiont-bearing benthic foraminifera and responses to a high $\mathrm{CO}_{2}$ environment, J. Exp. Mar. Biol. Ecol., 424-425, 15-24, 2012.

Wasmund, N., Pollehne, F., Postel, L., Siegel, H., and Zettler, M. L.: Biologische Zustandseinschätzung der Ostsee im Jahre 2004, Meereswissenschaftliche Berichte, 64, IOW, Warnemünde, 2005.

Wasmund, N., Pollehne, F., Postel, L., Siegel, H., and Zettler, M. L.: Biologische Zustandseinschätzung der Ostsee im Jahre 2005, Meereswissenschaftliche Berichte, 69, IOW, Warnemünde, 2006.

Wefer, G.: Umwelt, Produktion und Sedimentation benthischer Foraminiferen in der westlichen Ostsee, Reports Sonderforschungsbereich 95 Wechselwirkung Meer-Meeresboden, 14, 1-103, 1976.
Wefer, G. and Lutze, G. F.: Benthic foraminifera biomass production in the western Baltic Sea, Kieler Meeresforschungen, Sonderheft Nr. 3, 76-81, 1976.

Wefer, G. and Lutze, G. F.: Carbonate production by benthic Foraminifera and accumulation in the western Baltic Sea, Limnol. Oceanogr., 23, 992-996, 1978.

Wollast, R.: Evaluation and comparison of the global carbon cycle in the coastal zone and in the open ocean, in: The Global Coastal Ocean, edited by: Brink, K. H. and Robinson, A. R., John Wiley \& Sons, 213-252, 1998.

Wulff, F., Ertebjerg, G., Nicolaus, G., Niemi, A., Ciszewski, P., Schulz, S., and Kaiser, W.: The changing pelagic ecosystem of the Baltic Sea, Ophelia, Supplement, 4, 299-319, 1986.

Wulff, F., Stigebrandt, A., and Rahm, L.: Nutrient dynamics of the Baltic Sea, Ambio, 19, 126-133, 1990.

Yao, W. and Millero, F. J.: The Chemistry of the Anoxic Waters in the Framvaren Fjord, Norway, Aquat. Geochem., 1, 53-88, 1995. 